\title{
Pathological Considerations in Replacement Cardiac Valves
}

\author{
Frederick J. Schoen, MD, PhD,* Robert J. Levy, $\mathrm{MD}^{\dagger}$, and Henry R. Piehler, $\mathrm{ScD}^{\ddagger}$ \\ *Department of Pathology, Brigham and Women's Hospital and Harvard Medical School, \\ Boston, Massachusetts, \\ ${ }^{\dagger}$ Department of Pediatrics, University of Michigan, Ann Arbor, Michigan, and \\ ${ }^{\ddagger}$ Department of Metallurgical Engineering and Materials Science, Carnegie Mellon University, \\ Pittsburgh, Pennsylvania
}

The long-term outcome following cardiac valve replacement is primarily determined by three factors: irreversible cardiac and pulmonary pathology secondary to the valvular disease (especially left ventricular myocardial hypertrophy and degeneration, and pulmonary vascular disease), pre-existing cardiac disease, including congenital lesions and coronary arterial atherosclerotic occlusions, and prosthesis-host interactions. For most of the approximately 40,000 patients who undergo valve replacement each year in the United States, prosthesis-associated pathology is a a major determinant of prognosis. In this article, the significance, morphology, and pathogenesis of the major complications and other alterations during function of mechanical, bioprosthetic, and allograft valves are reviewed. Other reviews of pathologic considerations in cardiac valve replacement are available $(1-7)$.

\section{Structure and Function of Heart Valve Substitutes}

Heart valve prostheses respond passively to pressure and flow changes within the heart, and are generally classified into two types: mechanical and tissue. Mechanical valves are composed of synthetic, nonphysiological materials. In

Manuscript received April 30, 1991; revised May 28, 1991.

Address for reprints: Frederick J. Schoen, MD, PhD, Department of Pathology, Brigham and Women's Hospital, 75 Francis Street, Boston, MA 02115. contrast, tissue valves are composed, at least in part, of animal or human tissue. Bioprosthetic valves are usually fabricated from chemically-preserved (usually cross-linked) animal tissue, mounted on a prosthetic frame (stent). The other important tissue valve type is the human aortic valve allograft, processed but not cross-linked, that is implanted directly into the aortic root without a stent. Thus, although unmounted allografts can only be used as aortic valve replacements, stent-mounted allografts can be used to replace the mitral valve, and mechanical or bioprosthetic valves can be used in either site. Detailed descriptions of specific models of valve substitutes are available (8).

The Starr-Edwards caged-ball valve, Bjork-Shiley and Hall-Medtronic tilting-disk valves, and St. Jude Medical bileaflet tilting-disk valve have been the most widely used mechanical prostheses. The latter comprises approximately one-half of valve replacements done today. Three basic components constitute a mechanical valve prosthesis: the rigid, mobile, occluder (poppet) around which blood must flow, the cagelike superstructure that guides and restricts poppet motion, and the valve body or base. Most caged-ball valve occluders are composed of silicone rubber, but contemporary tilting-disk valve occluders are coated with pyrolytic carbon, a material with high strength, low propensity toward wear and fatigue, and high thromboresistance. Mechanical valve cages are constructed of nearly pure titanium (e.g., Hall-Medtronic) or cobalt-chromium alloy (e.g., Starr-Edwards, Bjork-Shiley). Some designs have carbon 
disks and supports (St. Jude). Blood flow through a mechanical valve prosthesis must course around the poppet; thus, these valves are somewhat obstructive to forward flow and frequently have areas of stasis distal to the orifice. The combination of stasis and nonphysiological surfaces yields a tendency toward thrombus formation; chronic anticoagulation therapy is thereby mandatory in patients with mechanical valves $(9,10)$.

Bioprosthetic heart valves generally have better hemodynamic efficiency and thromboresistance than mechanical valves. Flexible, trileaflet, biological tissue valves have a central orifice analogous to natural valves. Tissue valves are heterografts/xenografts (e.g., porcine aortic valve or bovine pericardial bioprostheses), homografts/allografts (e.g., aortic valves from either human cadavers or hearts removed at transplantation, with or without an aortic sleeve as a conduit), or autografts (e.g., composed of fascia lata or pericardium, or the patient's own pulmonary valve transplanted to the aortic root). The preferred terminology is xenograftallograft-autograft. Detailed terminology germane to tissue heart valves is summarized in reference 5. Stent-mounted porcine aortic valve bioprostheses, fabricated from a pig aortic valve preserved in glutaraldehyde $(0.2 \%$ for the Hancock and $0.6 \%$ for the Carpentier-Edwards), are widely used (presently approximately one-third of all valve replacements). In porcine bioprosthetic valves, the natural cuspal attachments to the aortic wall are maintained intact. Since the right coronary cusp of a pig (but not human) aortic valve is partially supported by septal myocardium, a porcine valve has a muscular shelf which extends into the right coronary cusp. This muscle can prevent full-opening of the cusp, be a site at which inflammation or tearing can occur, and/or aid in orienting the valve for analysis. Valve obstruction related to impaired opening of the right coronary cusp can be of importance in a porcine bioprosthesis of relatively small size. A modified orifice Hancock prosthesis for small sizes has a cusp without a muscular ridge substituted from another valve, as a means of widening the valve inlet area (11).

Pericardial valves were used in the last decade but are not presently implanted in the United States. Each cusp of a pericardial valve is an individual piece of glutaraldehydetreated parietal pericardium (usually of bovine origin) that is attached to the frame. Various designs of pericardial bioprostheses differ widely in their method of mounting the tissue on the frame.

Cuspal structure and hence physical properties of porcine aortic valve and bovine pericardium are different $(4,5,12$ 14). The structure of natural aortic valve cusps is highly specialized for function. Material properties in the plane of the tissue are anisotropic (not the same in all directions), reflecting the nonrandom orientation of architectural elements that effectively transmits stress to the aorta. Moreover, aortic valve cusps (porcine or other species) have three layers: the predominantly collagenous ventricularis, near the inflow surface; the central spongiosa, with loosely arranged collagen and abundant amorphous extracellular matrix, and the fibrosa, with densely packed collagen, facing the outflow surface. In contrast, pericardial tissue is a relatively homogeneous sheet of laminated collagen without clear layers; properties are similar in all directions (isotropic). Generally, the smooth side of the pericardium (formerly the serosa) forms the cuspal outflow aspect and the rough surface is the inflow.

A fabric sewing cuff (usually Dacron) that surrounds the base of both mechanical and tissue prostheses facilitates suturing the device into the surgically prepared annulus. In most cases, organized thrombus or fibrous tissue derived from the adjacent myocardium or aortic wall ultimately covers the rough cloth surface. The tissue-valve interface is sealed by adherent tissue in most cases, but the strength of the valve-tissue bond is primarily provided by the sutures. Although sewing cuff configurations differ slightly for semilunar and atrioventricular sites, prosthetic valves used in either site are otherwise virtually identical.

\section{Prosthesis-Related Complications}

Within 10 years postoperatively, valve-related complications occur in approximately $50 \%$ or more of patients having previously and currently used substitute valves (15). Reoperations, almost always necessitated by valve-related complications, presently account for approximately $20 \%$ of all valve surgery. Furthermore, many patients die from prosthesis complications; prosthesis-related events cause approximately half of late deaths (16). Valve prosthesis patholugy revealed by autopsy is often clinically unappreciated. Nevertheless, although most large studies show little difference in overall valve-related complication rates between mechanical prostheses and bioprostheses at 10 years, the frequency and, in some cases, the nature of specific valve-related complications varies widely with the type, model and site of the replacement device (as well as with patient characteristics) (4).

The most frequent valve-related complications in patients with mechanical or bioprosthetic valves are thromboembolic problems (including anticoagulant-related hemorrhage), infective endocarditis, paravalvular leak, intrinsic degradative dysfunction, and extrinsic interference with function, usually by tissue overgrowth (Table 1) (17). The causes of failure of 112 consecutive porcine bioprostheses and 45 mechanical valve prostheses surgically removed at our hospital during 1980-1985 included thrombosis (9\%), tissue overgrowth $(5 \%)$, endocarditis $(16 \%)$, paravalvular leak $(11 \%)$, and degenerative dysfunction $(53 \%)(18)$. Thrombosis, a major cause of mechanical valve dysfunction ( $18 \%$ of their failures), was infrequent with bioprostheses. In contrast, $74 \%$ of removed bioprostheses had primary tissue degeneration. Thus, in selecting a substitute valve for a specific patient, a surgeon generally weighs the risks of thromboembolic complications of mechanical prostheses versus the limited long-term durability of bioprostheses. Moreover, thromboembolic complications are frequently 
Table 1. Mortality and Morbidity Following Cardiac Valve Replacement

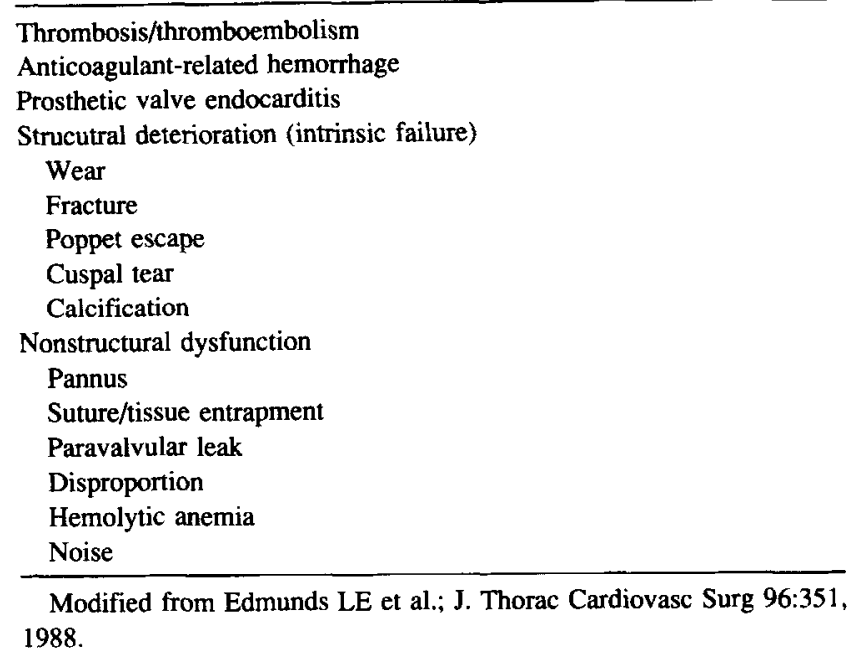

catastrophic and fatal. In contrast, bioprosthetic valve dysfunction infrequently causes precipitous clinical deterioration (only 5 to $10 \%$ of patients require reoperation emergently) (19). Patients with intrinsic bioprosthetic valve failure that is recognized promptly can usually be reoperated with an operative mortality not substantially higher than that of primary valve replacement surgery (20).

Thromboembolic complications. Thromboembolic complications include thrombosis, thromboembolism, and anticoagulation-related hemorrhage. Thrombotic occlusion and thromboemboli can occur with all currently available types of prostheses, at rates of 1 to $4 \%$ per patient-year; actuarial freedom from thrombosis or thromboembolism at 10 years for patients with either porcine bioprostheses (usually without anticoagulation) or tilting disk prosthetic valves (with anticoagulation) is typically 70 to $80 \%(9,15)$. The risk of thromboembolism depends on the specific prosthesis used and adequacy of anticoagulation (particularly high in poorly anticoagulated patients with mechanical valves), cardiac rhythm (increases with atrial fibrillation), and anatomic site of valve replaced (mitral $>$ aortic). Thromboembolic complications occur most frequently in the first postoperative year, in part due to thrombogenicity of the valve sewing ring prior to tissue incorporation. Nevertheless, traditional chronic oral anticoagulation carries a risk of hemorrhage, particularly retroperitoneal, gastrointestinal or cerebral, with a frequency approximately $4 \%$ per patient year, of which 15 to $25 \%$ of events are fatal (21). Consequently, there is considerable interest in developing less intense anticoagulation regimens. Although customary practice aims for maintaining the prothrombin time at 1.5 to 2.5 times normal, recent studies suggest that a target of 1.3 to 1.5 times normal maintains low rates of thromboembolism without excessive hemorrhagic risk (22).

Prosthetic heart valve thrombi, either red (fibrin) or white (platelet), can impair occluder opening or closing or gen-
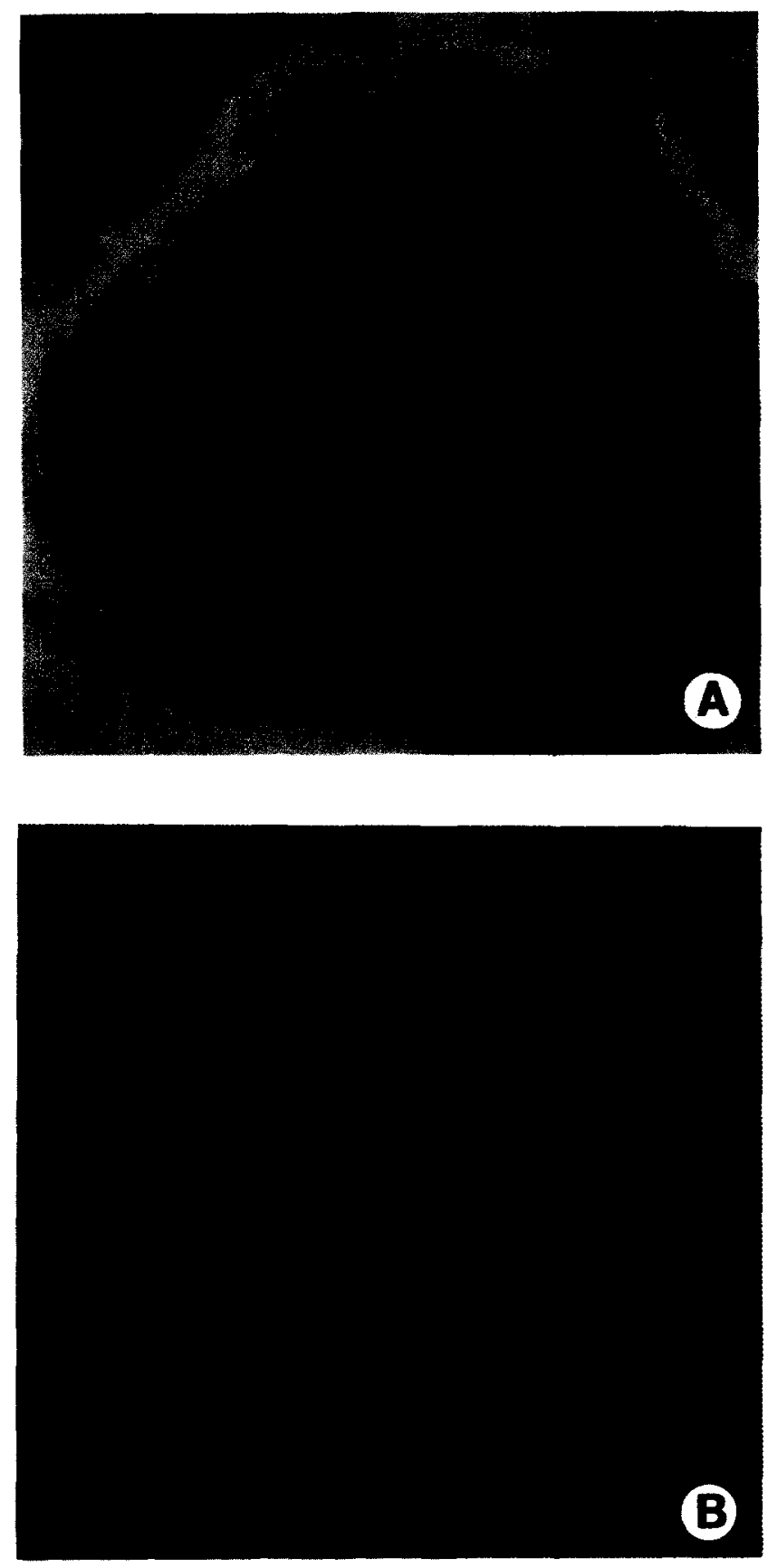

Figure 1. Prosthetic valve thrombosis. A. Aortic Bjork-Shiley tilting disk valve prosthesis, viewed from distal (outflow) aspect, demonstrating localization of thrombus to outflow strut near minor orifice, the site of flow stasis (arrow). B. Porcine aortic valve prosthesis, from distal (outflow) aspect, demonstrating thrombotic deposits in two of three sinuses of Valsalva.

erate thromboemboli to distal arterial beds. Clinicallydetectable thromboemboli most frequently (over 80\%) involve the central nervous system. Since the lack of adjacent vascular tissue retards typical histologic organization, bioprosthetic or mechanical valve-associated thrombi are fri- 
able for extended periods. Similarly, determination of duration of a thrombus on a prosthesis is nearly impossible.

The relative propensity for and sites of thrombus on specific valve prostheses are determined by surface thrombogenicity, hypercoagulability, and locally static blood flow (Virchow's triad) (23). Valve sites where thrombi occur are associated with local hemodynamic disturbances, and designs having increased turbulence or well-defined regions of stasis yield higher rates of thromboembolism. For example, thrombi/thromboemboli arise at the cage apex of a cagedball prosthesis, a region of considerable flow abnormality (24), in contrast, a tilting disk prosthesis is particularly sus ceptible to thrombus formation in a stagnation zone in the minor orifice of the outflow region (Fig. 1A) (25). Thrombotic deposits on the cusps of bioprostheses involve one or more of the prosthetic sinuses of Valsalva (Fig. 1B); in most cases, no causal cuspal pathology can be demonstrated (26). Since platelet deposition dominates initial blood-surface interaction when valves and other cardiovascular devices are exposed to blood at high fluid shear stresses (27-30), antiplatelet agents are often administered in conjunction with anticoagulants $(10,31,32)$.

Prosthetic valve endocarditis. Infective endocarditis is infrequent (1 to $6 \%$ of patients with valve replacements), but serious (over $50 \%$ mortality) (33-35). Patients requiring valve replacement for native valve endocarditis frequently develop prosthetic valve endocarditis with the original organism. Infection rates of mechanical valves and bioprostheses are approximately the same. Complications of prosthetic valve endocarditis include embolization of vegetations, congestive heart failure secondary to valvular obstruction or regurgitation caused by bulky vegetations, or the consequences of local tissuc destruction.

Similar to other infections involving biomaterials, prosthetic valve endocarditis is resistant to host defense mechanisms and antibiotics, and thereby difficult to cure medically $(4,33)$. Infections of mechanical prostheses are almost always localized to the prosthesis-tissue interface at the sewing ring, causing a ring abscess, since synthetic biomaterials (polymers, metals, carbons) generally cannot support bacterial or fungal growth (Fig. 2A) $(36,37)$. The resultant tissue destruction may induce separation (dehiscence) of the prosthesis from the annulus, with regurgitation of blood around the prosthesis (paravalvular or paraprosthetic leak), or cause septic pericarditis, pseudoaneurysm, or complete or partial interference with atrioventricular conduction. Rarely, mechanical valve infection is confined to tissue associated with the valve superstructure or poppet (38).

Bioprosthetic valve endocarditis can be either localized to the prosthesis sewing ring and complicated by ring abscess, or confined to the cuspal tissue (Fig. 2B), often with tearing, perforation, or destruction leading to valve incompetence $(39,40)$. Cusps of bioprosthetic valves with endocarditis often have deep clusters of organisms with few inflammatory cells. Degenerating bacteria and inflammatory cells within cuspal vegetations of bioprosthetic valve endocarditis can undergo mineralization (extrinsic calcification) (Fig. 2C), often in a characteristic pattern that can rapidly suggest the diagnosis (Fig. 2D) (5).

Prosthetic valve endocarditis is generally classified as early (within 60 days following valve replacement) or late (after 60 days), with etiology, risk factors, and causative microorganisms different in each of these time periods. Organisms comprising normal skin flora predominate in early infections, emphasizing the importance of both valve contamination during implantation and early postoperative infection. Late infections are more likely to be precipitated by bacteremia associated with poor dental hygiene, dental or surgical procedures, or extracardiac pyogenic infections. The high frequency of staphylococcal infection on prosthetic valves (Staphylococcus epidermidis, Staphylococcus aureus), particularly in early cases, contrasts with the relatively low frequency of these organisms in natural valve endocarditis; streptococci, gram-negative bacilli and fungi also are prevalent. In about $15 \%$ of cases, a causative organism cannot be cultured. Although some of these infections could be caused by anaerobes, culture-negative prosthetic valve endocarditis has been recently related to legionella (41) and $Q$ fever (42).

Paravalvular leak (dehiscence, paraprosthetic leak) (Fig. 3). Early dehiscence is usually the result of technical error or separation of sutures from a pathologic annulus when valve replacement was done for endocarditis with ring abscess, myxomatous degeneration or calcified aortic valve or mitral annulus (43). In contrast, late, small paravalulvar leaks are usually caused by tissue retraction from the sewing ring between sutures during healing. Small periprosthetic defects are often clinically inconsequential; large tears can aggravate or cause hemolysis or heart failure. A valve removed for paravalvular leak appears unremarkable to the surgical pathologist; detection at autopsy may require careful probing.

\section{Durability Considerations}

Prosthetic valve failure is frequently precipitated by the limited durability of biomaterials. Specific failure modes vary widely for mechanical valves and bioprostheses, and frequently, for specific types of each, for prostheses utilizing different materials or design features, or for the same model placed in the aortic rather than the mitral site (4).

Mechanical prostheses. Silicone elastomeric ball occluders of early caged-ball prostheses absorbed blood lipids, causing swelling, distortion, cracking, and embolization of poppet material or abnormal poppet movement (ball variance), particularly in the aortic position (Fig. 4A) (44). Lipid-related ball variance was subsequently eliminated by changes in elastomer fabrication in 1964. With cloth covered, caged-ball valves used to provide a substrate for tissue overgrowth, abrasion by the occluder often induced frag- 

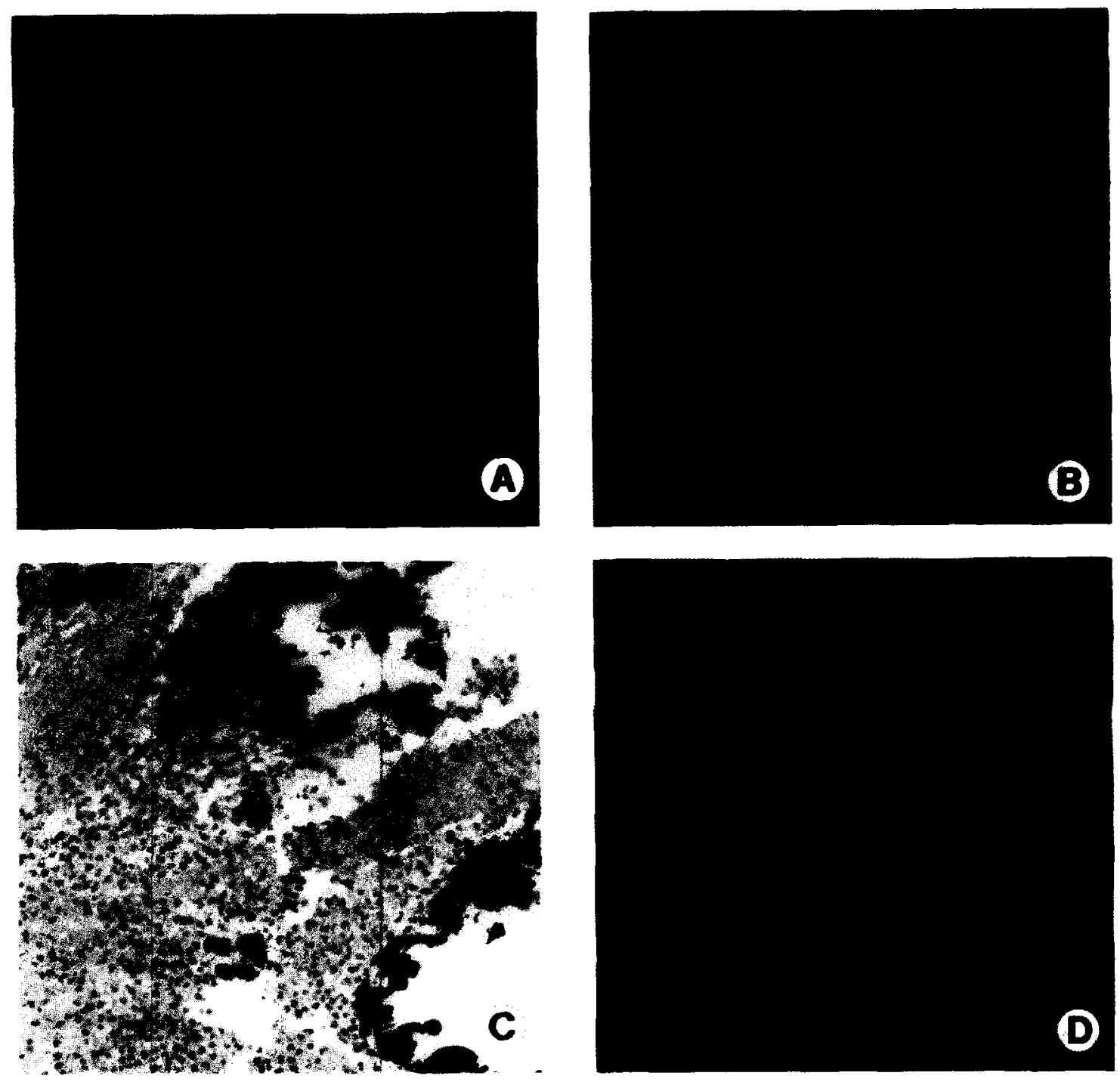

Figure 2. Prosthetic valve infective endocarditis. A. Ventricular view of mitral tilting disk prosthesis in patient dying of infective endocarditis. Large bulky vegetations consisting of bacterial organisms and platelet/inflammatory cell/fibrin thrombus cover part of the sewing ring and form an abscess within tissue of the annulus (arrow) (Reproduced by permission from Schoen FI. Cardiac valve prostheses: pathological and bioengineering considerations. J. Cardiac Surg 1987; 2:65-108. (c) 1987, Futura Publishing Company.) B. Bioprosthetic bacterial endocarditis involving cusps, viewed from inflow aspect; large vegetations are apparent. (Reproduced by permission from Schoen FJ and Hobson CE Anatomic analysis of removed prosthetic heart valves: causes of failure of 33 mechanical valves and 58 bioprostheses, 1980-1983. Hum Pathol 1985; 16:549-559. (C) 1985, W.B. Saunders.) C. Photomicrograph of calcified endocarditic vegetation on porcine bioprosthetic valve $(\mathrm{H} / \mathrm{E} \times 175)$. D. Radiograph of infected porcine bioprosthetic valve with calcified vegetations, demonstrating diffuse distribution of calcific deposits characteristic of endocarditis.

Figure 3. Paravalvular leak, mitral prosthesis, viewed from left atrium (probe in defect). (Reproduced by permission from Schoen FJ. Pathology of caridac valve replacement. In: Morse, D, Steiner RM, Fernandez J, eds. Guide to Prosthetic Cardiac Valves. New York: Springer Verlag, 1985:209-238.)

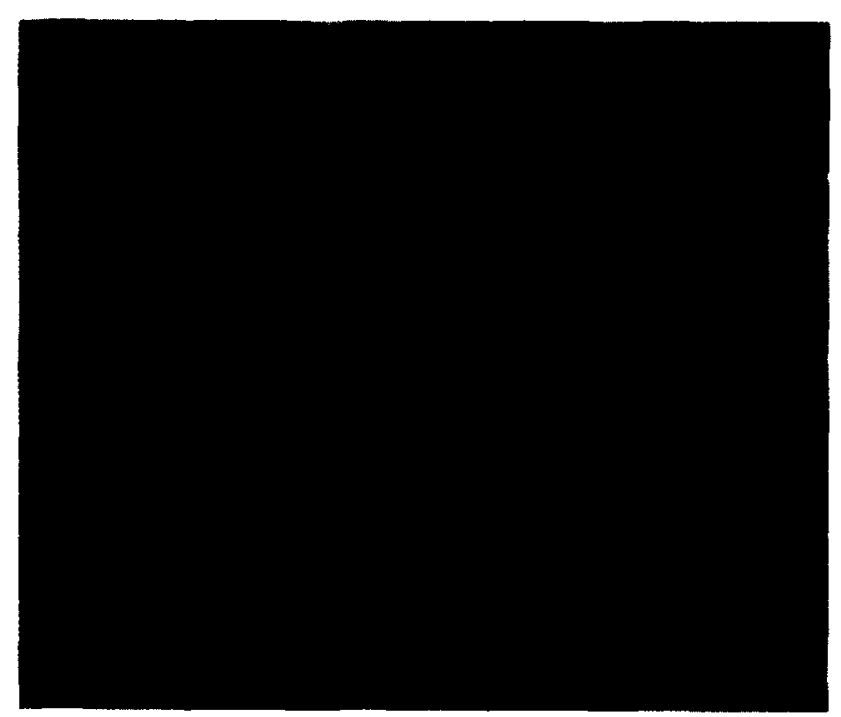


mentation of cloth, thrombosis, fibrous overgrowth and resultant ball entrapment (models with metal poppets), or poppet escape (in aortic, but not mitral, models with silicone occluders, due to mutual cloth-poppet abrasive wear) (Fig. 4B) $(45,46)$. Nevertheless, structural failure of presently used caged-ball prostheses is rare. Caged-disk valves with plastic disks suffered disk wear and resultant valve incompetence, and are no longer used $(47,48)$; plastic-coated stents can also wear down (Fig. 4C). Since microfragments of worn nonphysiologic material may embolize systemically, demonstration of foreign body granulomas on biopsy of the liver or other organs may aid the recognition of ball or disk variance (49).

Contemporary tilting disk designs with pyrolytic carbon occluders, with or without carbon cage components, have generally favorable durability. Fractures of metallic or carbon valve components and escape of parts from such valves rarely occur. (50-52). However, in a specific cohort of Bjork-Shiley 60 and $70^{\circ}$ convexo-concave (C-C) heart valves, the welded outlet strut has fractured and separated from the valve, leading to disk escape that is frequently fatal (Fig. 4D). Over 300 such cases are known; in each fractured valve, the previously completely machined housing (integral) was replaced by a housing in which the outflow strut was welded to the housing. Fatigue failure of the welded metallic joint likely precipitates the fracture of this valve $(53,54)$. This problem is discussed in detail below.

In contrast to the free disk rotation of contemporary tilting disk valves, bileaflet disk valves have a fixed pivot point at the periphery of each disk; the configuration varies with specific manufacturer and design. Fractures of components of the St. Jude valve are rare; however, at least 17 cases of leaflet cscape from the Edwards-Duramedics bileaflet valve have been reported (Fig. 4E) (55). Detailed pathologic studies of removed valves not suffering overt structural dysfunction may be useful in predicting long-term durability $(56,57)$.

Bioprostheses. The major cause of bioprosthetic valve dysfunction is primary tissue failure, especially when it is related to cuspal mineralization (58-61). Noninfective tissue degeneration (primary tissue failure) of glutaraldehyde-pretreated porcine bioprostheses is strongly time dependent. In adults, less than $1 \%$ of valves implanted for 5 years have failed, 20 to $30 \%$ fail within 10 years, and more than half are no longer functional by 15 years postoperatively. Regurgitation through tears forming adjacent to calcific nodules is the most frequent failure mode (Fig. 5A); pure calcific stenosis (Fig. 5B) and noncalcific cuspal defects are less frequent $(1,4,61)$; rarely, important emboli arise from calcific valves (Fig. 5C) (62). Noncalcific tissue tears, revealed by scanning electron microscopy as fraying and disruption of collagen fibers, usually reflect direct mechanical damage to collagen (63).

The amount of calcification of removed valves after longterm implantation is highly variable (64). Although calcifi- cation is noted in almost all porcine aortic valve bioprostheses implanted for at least 4 years, valves with minimal or no calcific deposits are occasionally encountered after 10 years or more. Calcification is markedly accelerated in bioprostheses implanted in children, adolescents, and young adults $(1,65)$.

Degenerative cuspal calcific deposits form within the cusps (intrinsic mineralization), and are composed of calcium phosphates, closely related to physiologic bone mineral (hydroxyapatite). Calcific deposits generally predominate at the cuspal commissures and basal attachments, are grossly visible as nodular gray/white masses that often ulcerate through the cuspal tissue, and are most extensive in the porcine valve spongiosa layer. Ultrastructurally, calcific deposits are associated with connective tissue cells and collagen $(66,67)$.

Pericardial bioprostheses also suffer calcific degenerative failure in both adults and children $(68,69)$. However, noncalcific cuspal perforations and tears more frequently cause failure of clinical pericardial bioprostheses (70-72). Defects occur near the cuspal attachments and are usually related to either continuous trauma of the tissue against the Dacron cloth strut covering, causing abrasion (Fig. 6A), or fatigue of the tissue near the free edge of the leaflet, adjacent to the stent post (Fig. 6B).

Other tissue valves. Noncommercial, hospital-made autologous and homologous tissue valves constructed from pericardium, fascia lata, or dura mater mounted on clothcovered metal stents have also been used. Clinical studies reveal extremely high failure rates, with removed valves having thick connective tissue overgrowth, cuspal stiffening and shrinkage, calcification, and tearing $(4,5,73,74)$. In contrast, unstented, cadaver-derived aortic homografts, used for selected patients with isolated aortic valve disease or congenital malformations, have excellent short- and mediumterm function (75-78). Pathologic issues related to valve allografts are discussed below.

\section{Miscellaneous Valve-Related Pathology}

Prosthetic valves are not only partially obstructive to forward flow but also have some variable regurgitant flow, often intentionally designed into the mechanism to enhance closing. The increased hemodynamic burden of the resultant chronic pressure and/or volume overload probably contributes to progressive myocardial deterioration in some patients. Contemporary tilting and bileaflet tilting disk valves and bioprostheses have favorable hemodynamic performance $(79,80)$. However, bioprostheses can be significantly obstructive, particularly in small sizes, where the bulk of the struts is not proportionally reduced. Moreover, inward deflection of the stent posts (stent creep) during function of some porcine bioprostheses may contribute to progressively increasing stenosis (Fig. 7) (81). Prostheses inappropriately large for the anatomic site of implantation can have re- 

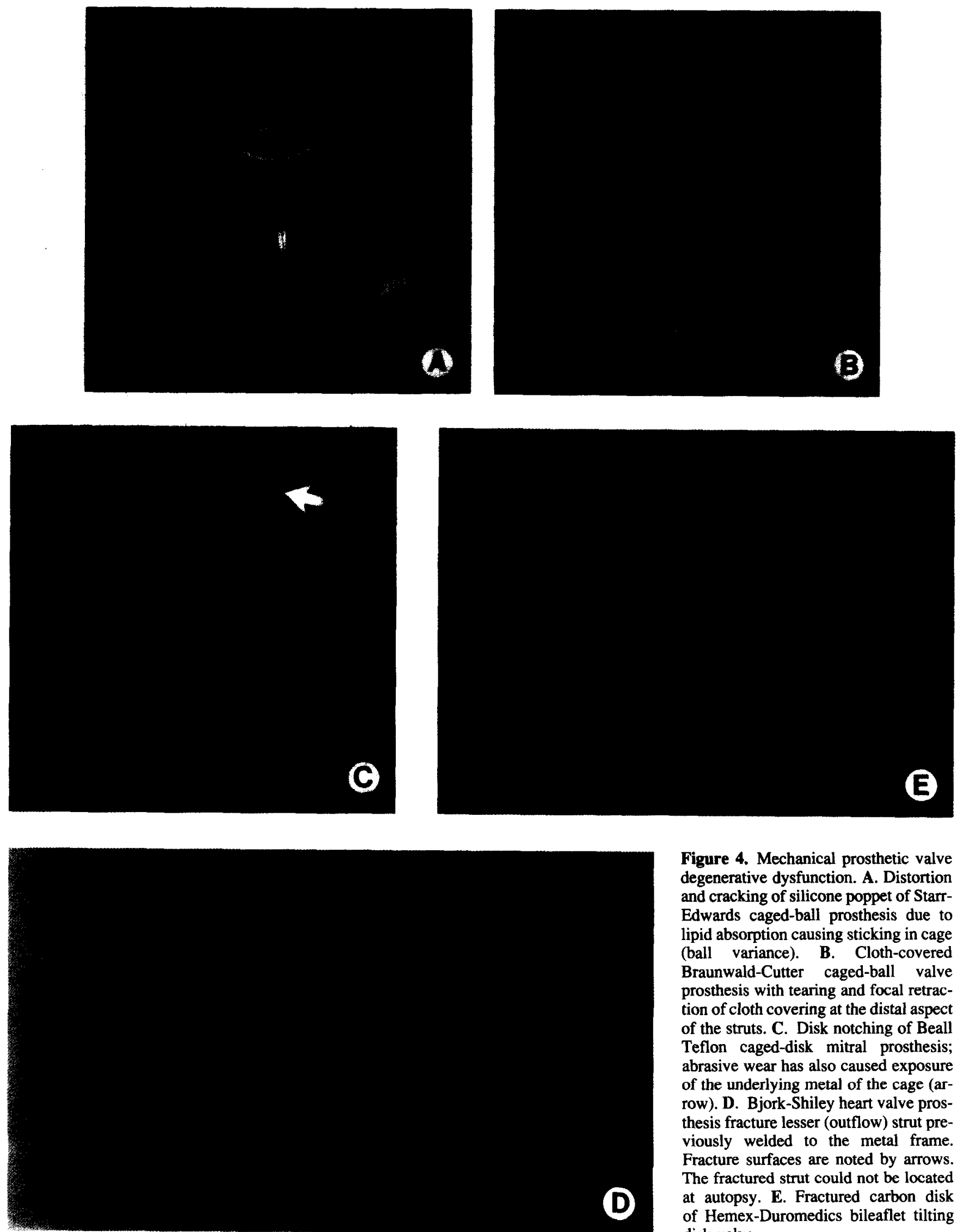

Figure 4. Mechanical prosthetic valve degenerative dysfunction. A. Distortion and cracking of silicone poppet of StarrEdwards caged-ball prosthesis due to lipid absorption causing sticking in cage (ball variance). B. Cloth-covered Braunwald-Cutter caged-ball valve prosthesis with tearing and focal retraction of cloth covering at the distal aspect of the struts. C. Disk notching of Beall Teflon caged-disk mitral prosthesis; abrasive wear has also caused exposure of the underlying metal of the cage (arrow). D. Bjork-Shiley heart valve prosthesis fracture lesser (outflow) strut previously welded to the metal frame. Fracture surfaces are noted by arrows. The fractured strut could not be located at autopsy. E. Fractured carbon disk of Hemex-Duromedics bileaflet tilting disk valve. 

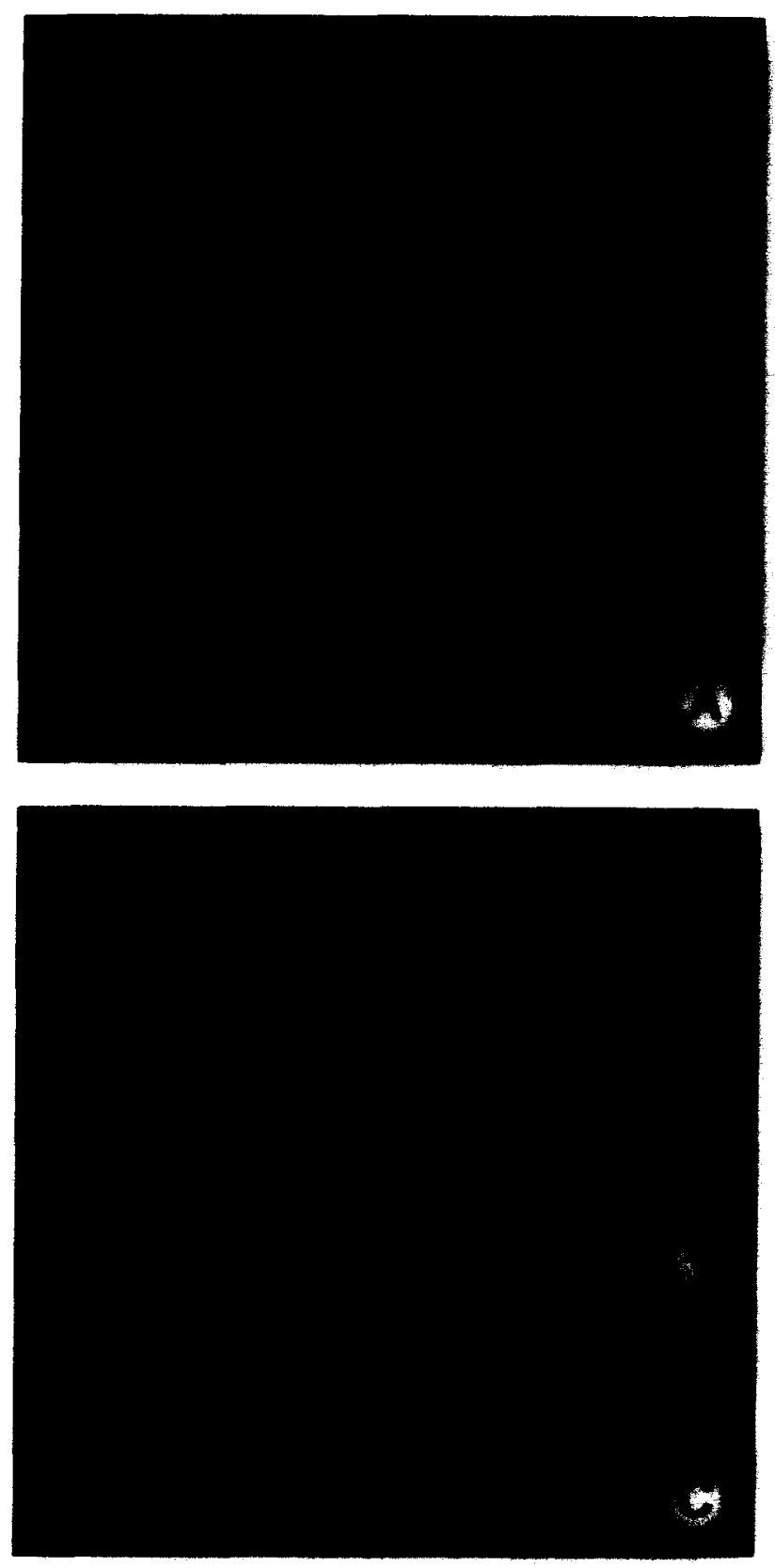

stricted poppet motion, impinge on surrounding structures, or be obstructive, since flow around the poppet may be impeded (prosthetic disproportion) (82). Mitral prostheses too large for the ventricle into which they are placed can interfere with left ventricular filling or emptying.

Factors extrinsic to a prosthesis can promote stenosis or regurgitation (82-95). A trend in mitral valve replacement surgery is the retention of as much of the mitral apparatus as possible, in the belief that this enhances postoperative left ventricular function (83). However, either retained valve remnants or unraveled or excessively long ends of sutures can interfere with valve occluder motion (Fig. 8). A large

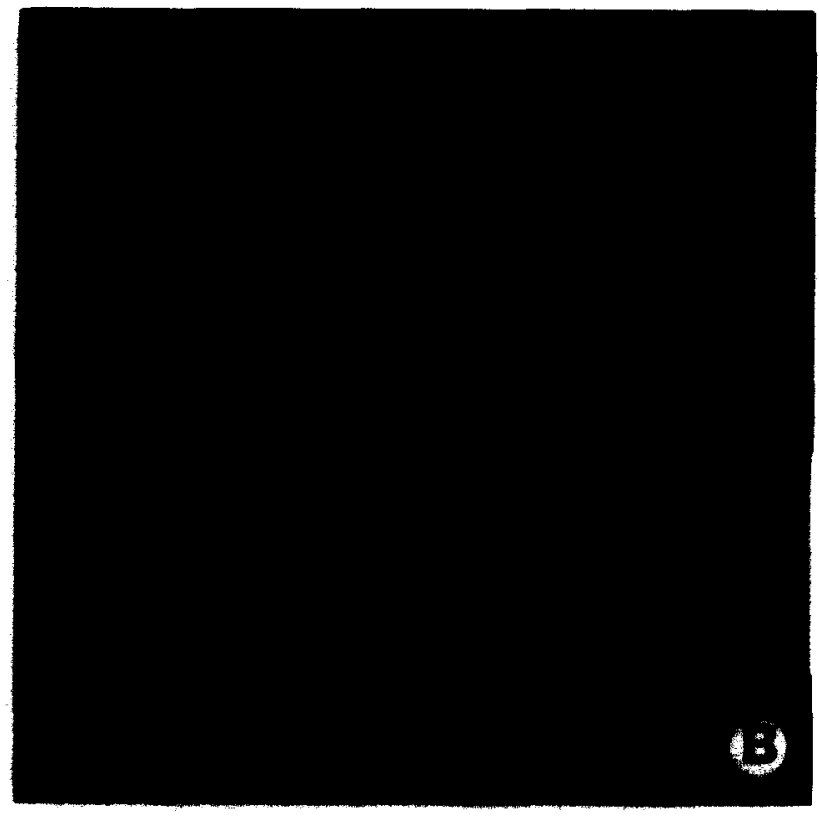

Figure 5. Porcine bioprosthetic valve calcific failure. A. Calcific stenosis, B. Calcification with secondary tear. (A and B are reproduced by permission from Schoen FJ and Hobson CE. Anatomic analysis of removed prosthetic heart valves: causes of failure of 33 mechanical valves and 58 bioprostheses, 1980-1983. Hum Pathol 1985; 16:549-559. Copyright 1985, W.B. Saunders.) C. Calcification, tearing and calcific embolus (arrow) removed from left anterior descending coronary artery.

mitral annular calcific nodule or septal hypertrophy can prevent full excursion of a mitral tilting disk valve occluder. Exuberant overgrowth of fibrous tissue can obstruct the inflow orifice of any valve (Fig. 9), prevent full mechanical valve occluder excursion, or cause stenosis or regurgitation of bioprostheses. Intermittent sticking of tilting disk prostheses has been recognized; sometimes, such valves appear to function normally when removed, and the cause of malfunction remains obscure, despite careful pathologic examination. Sutures may be looped around bioprosthetic valve stents, particularly with pericardial bioprostheses, restricting cuspal motion, and suture ends cut too long may perforate a bioprosthetic valve cusp (1).

Some red blood cell destruction by the turbulent flow in prosthetic heart valves is common, but hemolysis is generally slight and well compensated; severe hemolytic anemia is unusual without paravalvular leaks or valvular dysfunction (96-98). Renal tubular hemosiderosis or cholelithiasis noted at autopsy suggests chronic hemolysis $(99,100)$.

The spectrum of morphologic changes that occurs prior to and following bioprosthesis implantation and the specific differences between porcine aortic valve and bovine pericardium are summarized elsewhere $(5,7,101-105)$. Systemic diseases can also involve bioprosthetic valves (106, 107). 

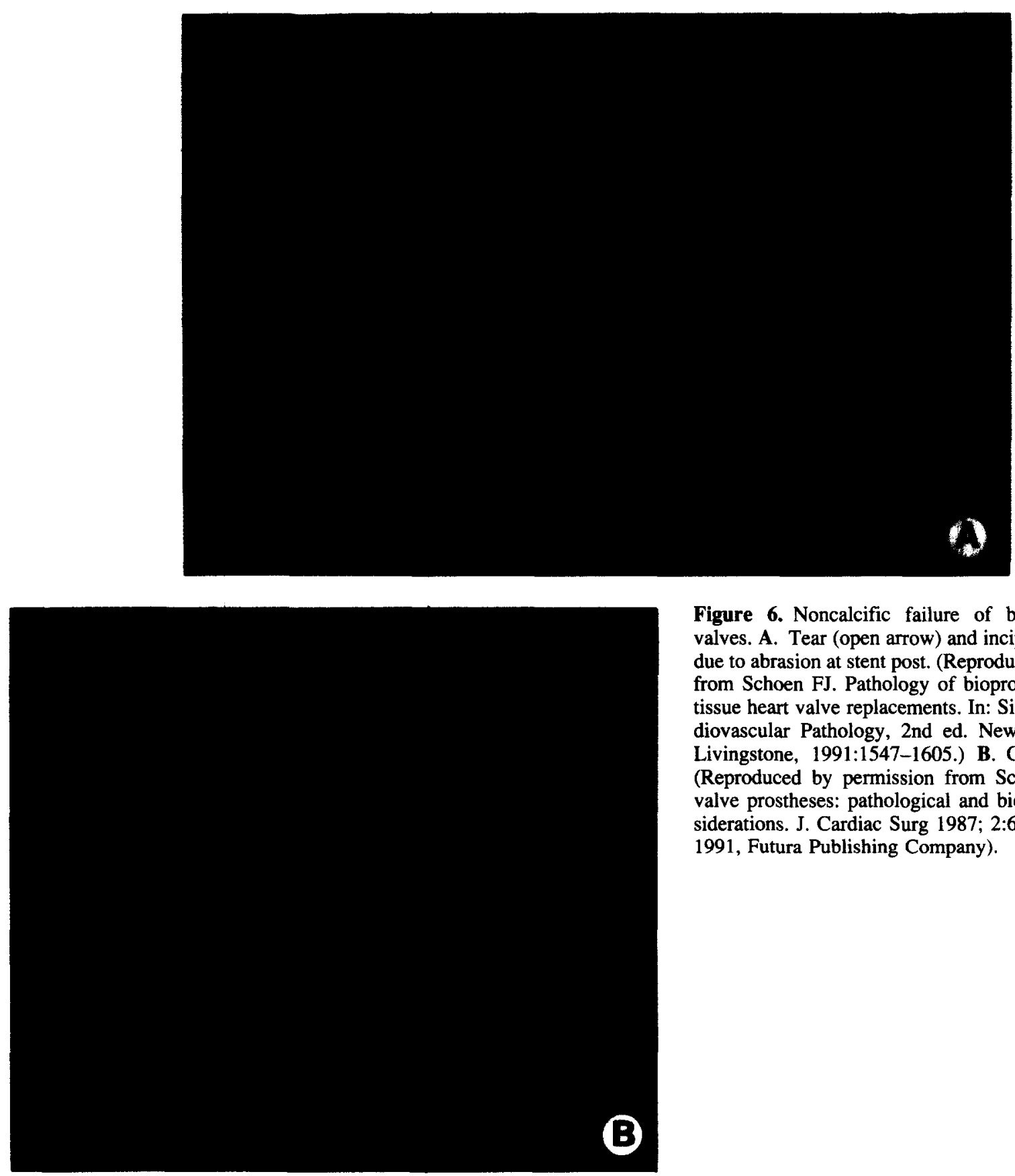

Figure 6. Noncalcific failure of bovine pericardial valves. A. Tear (open arrow) and incipient tear (arrow), due to abrasion at stent post. (Reproduced by permission from Schoen FJ. Pathology of bioprostheses and other tissue heart valve replacements. In: Silver MD, ed. Cardiovascular Pathology, 2nd ed. New York: Churchill Livingstone, 1991:1547-1605.) B. Commissural tear. (Reproduced by permission from Schoen FJ. Cardiac valve prostheses: pathological and bioengineering considerations. J. Cardiac Surg 1987; 2:65-108. Copyright 1991, Futura Publishing Company).

\section{Aortic Valve Allografts}

Homograft/allograft aortic valves are advantageous for selected patients with aortic valve disease or those requiring pulmonic valve and/or pulmonary artery replacement for congenital heart disease (3,75-78). Allograft aortic valve/ root replacement is considered a useful method for management of active endocarditis complicated by annular destruction and for surgical treatment of many kinds of congenital heart disease where the creation of a pathway from a ventricle to the pulmonary arteries is necessary (108). Representative failure rates are 19 to $50 \%$ at 10 to 12 years and 54 to $89 \%$ at 15 to 20 years for variously prepared valves, including chemically-treated and antibiotic-sterilized allografts (75-78). In general, however, results for contemporary allograft heart valves appear to be somewhat better than those using obsolete tissue treatments, and it is well accepted that the time course of failure of allografts is slower than that for other tissue valves, especially in a young population. Thus, 


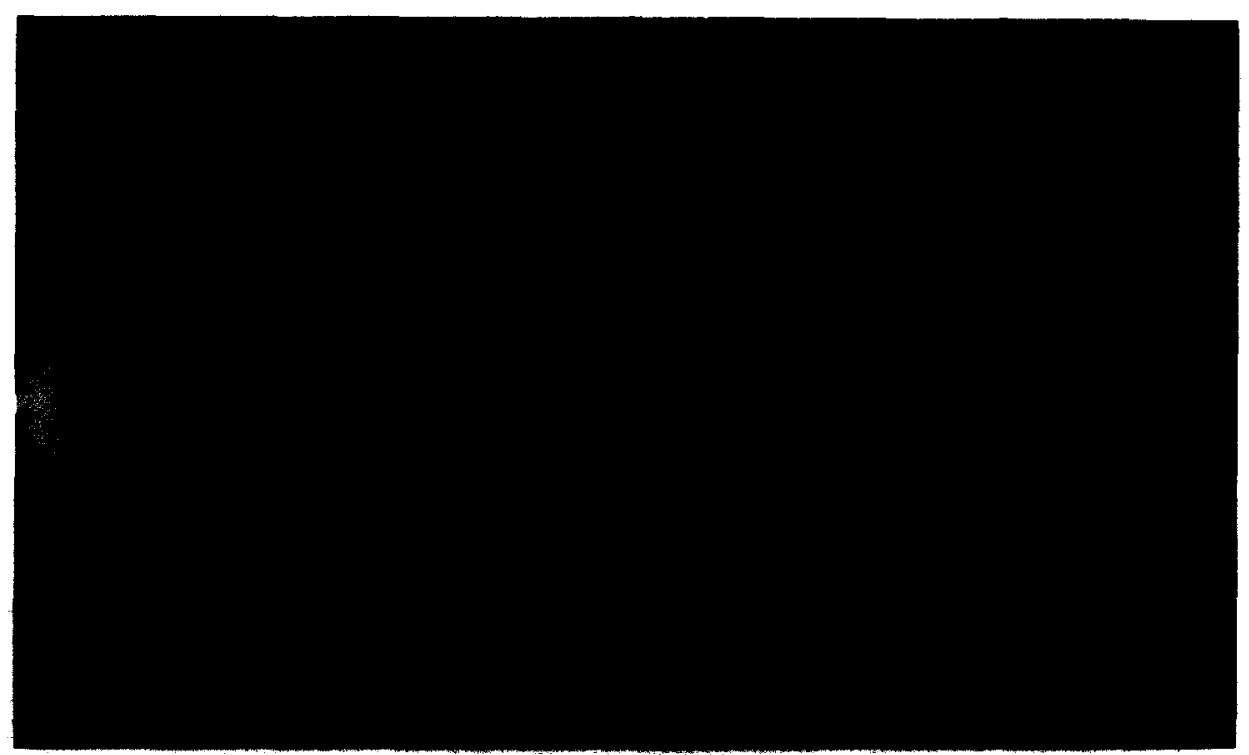

Figure 7. Stent creep of porcine bioprosthesis. Left, a $25-\mathrm{mm}$ aortic prosthesis implanted for 36 months; compromise of the outflow orifice is apparent. Right, an unimplanted 25-mm prosthesis for comparison. (Reproduced by permission from Schoen FJ, Schulman LJ, Cohn LH. Quantitative anatomic analysis of "stent creep" of explanted Hancock standard porcine bioprostheses used for cardiac valve replacement. Am J Cardiol 1985; 56:110-114. Copyright 1985, Yorke Medical Publishers).

the allograft, when available, is the replacement of choice in many centers. Current interest is directed toward allografts cryopreserved in liquid nitrogen at $-196^{\circ} \mathrm{C}$ using dimethyl

Figure 8. Interference with tilting disk valve occluder motion by suture with long cut end (arrows). (Reproduced by permission from Schoen FJ. Surgical Pathology of removed natural and prosthetic heart valves. Hum Pathol, 1987; 18:558-567. Copyright 1987, W.B. Saunders.)

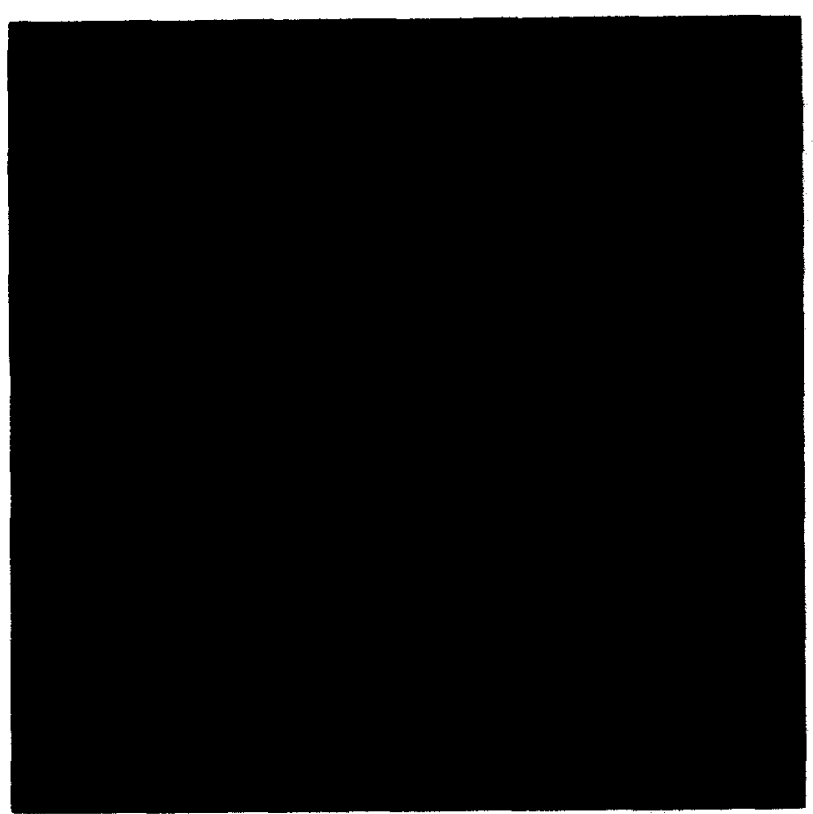

sulfoxide (DMSO) as a protective agent; some studies suggest that these valves perform significantly better than antibiotic-treated grafts $(75,78)$. The major advantages of allografts are excellent hemodynamic performance, nearly equivalent to that of the natural aortic valve, and an exceedingly low rate of thromboembolism (less than $4 \%$ total up to

Figure 9. Tissue overgrowth compromising inflow orifice of porcine bioprosthesis. 
15 years, compared to 1 to $4 \%$ per year for mechanical and bioprosthetic valves). Nevertheless, failure resulting from progressive degeneration occurs frequently, with incompetence the major limitation generally caused by cuspal rupture, distortion with retraction, or perforations $(76,77)$. The relative advantages and disadvantages of mechanical, bioprosthetic and allograft valves are summarized in Table 2 .

Allograft valves are historically obtained from cadavers, but many are now harvested from diseased hearts removed from cardiac transplant recipients. Early cadaver-derived allograft valves were procured aseptically and implanted within 1 to 3 weeks. However, due to logistical difficulties, valves were subsequently sterilized either chemically or by radiation, following nonsterile procurement. Such valves suffered a high rate of leaflet calcification and rupture (109113). Antibiotic-sterilized but not cross-linked valves, used more recently, are often considered "fresh," but they are essentially nonviable. Although studies suggest that some metabolic activity and viable cells may remain in the grafts at the time of implantation of valves cryopreserved using current technology (114), it is unknown whether allograft cell viability at implantation time is an important determinant of long-term durability. Impetus to achieve cell viability may be a search for a more "gentle" treatment of the valve that may preserve other important elements, such as extracellular matrix, irrespective of the state of the cells. Moreover, the presence of viable cells could be deleterious, for example, by potentiating immunological reactivity (115) or calcification.

Pathologic features noted in removed failed or nonfailed aortic valve allografts are illustrated in Figure 10 and summarized in Table 3 . Nearly all valves removed following various periods of implantation are devoid of surface endothelium and deep connective tissue cells of both valve cusps and contiguous aortic wall. Inflammatory cellularity is variable. Late explants frequently have some degree of proximal intimal fibrous sheath, aortic wall calcification and, occasionally, cuspal calcific deposits $(116,117)$. Stentmounted aortic allografts used for mitral valve replacement

Table 2. Allograft Valve Morphology

Nearly All Valves

Loss of cuspal connective tissue cells

Loss of endothelium

Minimal inflammatory cellularity

Aortic wall calcification

None to minimal cuspal calcification

Intimal fibrous sheath

Occasional Valves

Cuspal distortion

Cuspal tears

Suture line dehiscence

Commissural fusion

Mural thrombus

Fraying of cuspal free edge

Cuspal hematomas
Table 3. Major Merits and Problems of Contemporary Valve Substitutes

\begin{tabular}{lll}
\hline Mechanical valves & \multicolumn{1}{c}{ Advantages } & \multicolumn{1}{c}{ Disadvantages } \\
\cline { 2 - 3 } Bioprosthetic valves durable* & $\begin{array}{l}\text { More obstructive } \\
\text { Thrombogenic }\end{array}$ \\
Homograft valves & $\begin{array}{l}\text { Less obstructive } \\
\text { More thromboresistant }\end{array}$ & Less durable \\
& $\begin{array}{l}\text { Near-normal hemo- } \\
\text { dynamics } \\
\text { Thromboresistant } \\
\text { Slightly more durable }\end{array}$ & Limited availability \\
\hline
\end{tabular}

*Except for some models.

${ }^{\dagger}$ Except for small sizes.

often show detachment of the allograft tissue from the supporting stent posts with cuspal tears (118). Calcification of unstented aortic valve allografts occurs predominantly in the contiguous aortic wall, prominently involving elastic elements $(4,116)$.

Histocompatibility issues in the transplantation of heart valve allografts are not well established. Most allografts are not matched to the recipient's ABO blood group. Nevertheless, immunosuppression is generally not used. Significant lymphocytic infiltrate is unusual; the extent to which classical rejection contributes to failure is unknown.

Several tissue banks and one commercial organization are now procuring, processing, and distributing allograft valves in the United States. The Cardiovascular Devices Panel of the Food and Drug Administration recently developed a set of guidelines for heart valve allografts. Because of the paucity of retrieved devices and because most are removed at reoperations where the surgeon has difficulty removing the valve intact, allograft pathology has been relatively difficult to characterize. Previous detailed reports described pathologic features of valves using treatments no longer employed (108-113). Consequently, pathologists receiving explanted clinical allografts should make every effort not only to address pressing patient management questions but also to put the underlying changes of these valves in the context of larger pathologic concerns. Plans are underway to set up an evaluation protocol and establish a central registry for allograft pathology. In this respect, consideration should be given to the use of contemporary techniques of molecular forensics and DNA fingerprinting to assess cell lineage issues (i.e., donor vs. recipient).

\section{Pathologic Analysis of Contemporary Valve Substitutes}

The etiology of valve failure is documented by careful and informed examination of artificial valves, either removed or in situ, by surgical and autopsy pathologists. $\mathrm{Cu}-$ mulative data compiled by several case studies provides the basis for improved valve selection criteria, patient/prosthe- 

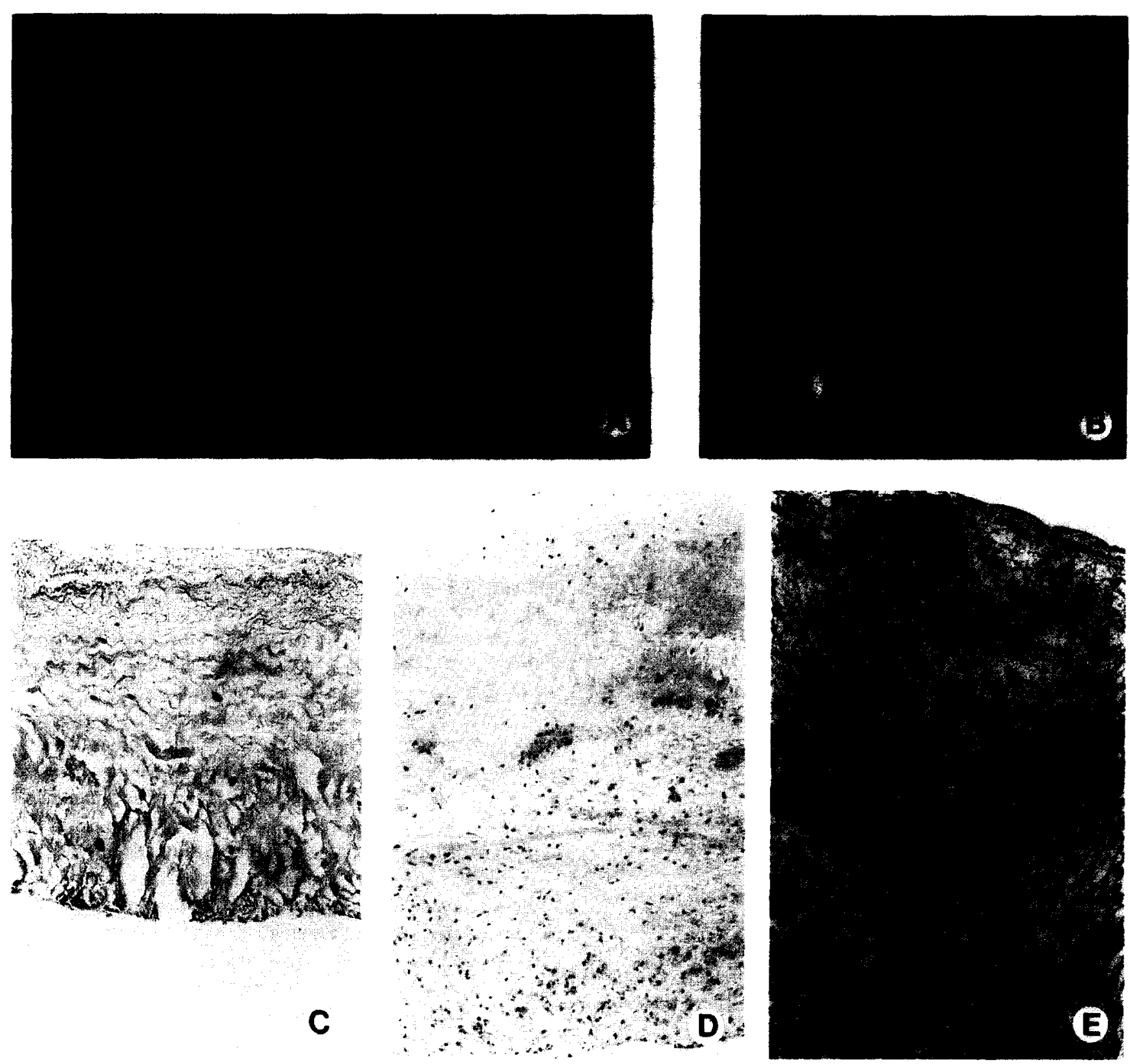

Figure 10. Allograft heart valve pathology. A. Aortic valve re moved as a result of cuspal laxity causing insufficiency (courtesy William D. Edwards, M.D., Mayo Clinic). B. Aortic homograft used as right ventricle to pulmonary artery shunt in infant with congenital heart disease. The aortic wall is heavily calcified and the valve cusps are variably shortened and retracted (arrow). C. Typical cuspal morphology with loss of original cellularity and few recipient inflammatory cells (hematoxylin $\&$ eosin $\times 175$ ). D. Aortic valve homograft with loss of cuspal cells, but moderate mononuclear inflammatory cellularity (hemotoxylin \& eosin $\times 100$ ). E. Immunoperoxidase staining demonstrating T-lymphocytic, origin of majority of cuspal cells in specimens shown in D, suggesting immunological process. (E) Immunoperoxidase using UCHL-1 antibody for T-lymphocytes (hemotoxylin \& eosin $x$ 150). (C) $175 \mathrm{X}$; (D) $100 \mathrm{X}$; (E) $150 \mathrm{X}$ sis matching, patient management strategies, and recognition of complications. Informed analysis of removed clinical and experimental prostheses often provides data not obtainable by either in vitro hemodynamic and durability tests or preclinical animal investigations, and elucidates mechanisms of patient-prosthesis and tissue-biomaterials interactions, thereby guiding potential improvements in valve design and materials. Pathologists have an important role in recognizing prosthesis-associated complications, a key element of the Safe Medical Devices Act of 1990 (PL101-629). This legislation requires hospitals to report to manufacturers and/or the FDA incidents in which a medical device has 


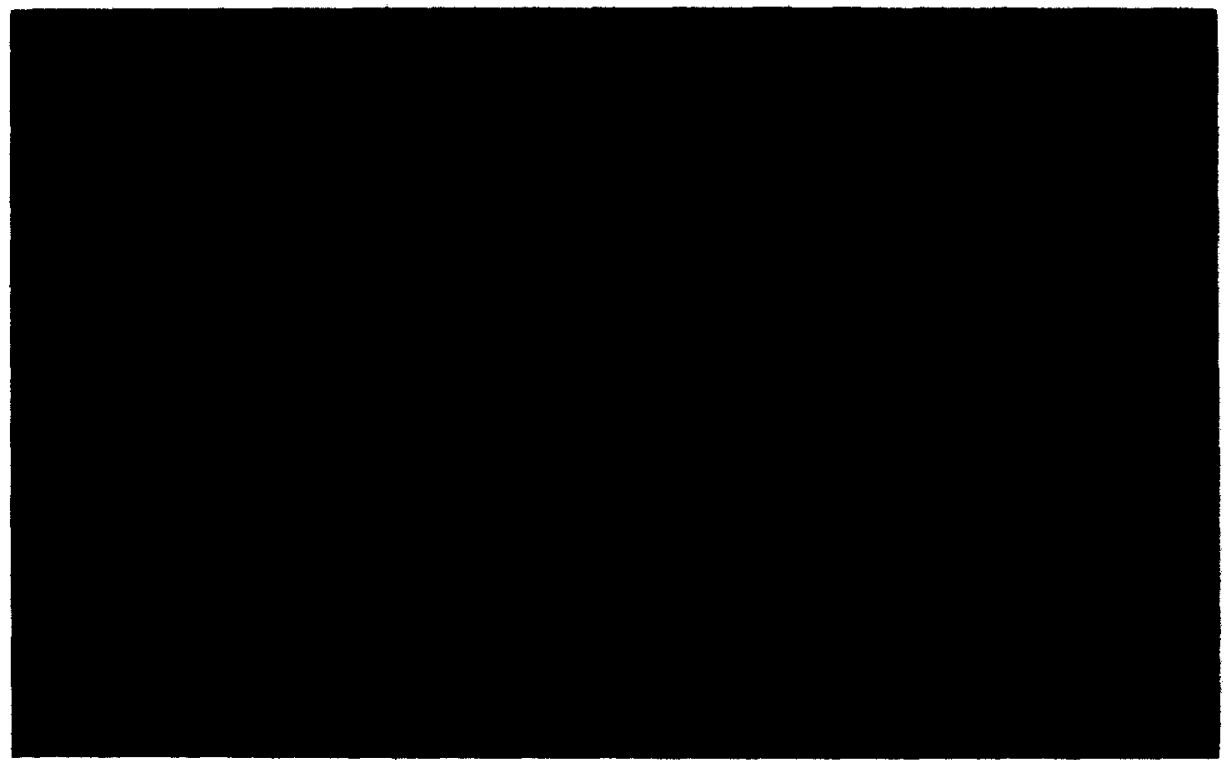

Figure 11. Opened porcine valve bioprosthesis, demonstrating superior visualization of cuspal tear. In this case, a catheter-induced tear was suggested.

caused or contributed to death of or serious injury to a patient.

Complete explant analysis includes gross examination and photography, radiography (for bioprostheses), dissection, histologic examination, and microbiologic cultures. Key morphologic features are summarized in Table 4. Special procedures, such as functional testing, dimensional analyses, surface topographic measurements, biochemical procedures, polarized light examination, or scanning or transmission electron microscopy can be used judiciously in experimental investigations of new valve materials or configurations and in clinical studies where specific clinicopathologic correlations are sought. While the anticipated pathology and thus the detailed protocol for analysis depends in large part on the type of prosthesis under consideration, generalized approaches to dissection of heart valve

Table 4. Pathological Analysis of Mechanical and Bioprosthetic Valves

\begin{tabular}{lll}
\hline \multicolumn{1}{c}{ Gross Examination } & Radiography & \multicolumn{1}{c}{ Histology } \\
\hline Tissue overgrowth & Valve identification & Vegetations/ \\
Thrombi & Calcification & Organisms \\
Vegetations & Degree & Thrombi \\
Cuspal stiffness & Localization & Host cell interactions \\
Cuspal hematomas & & Degeneration \\
Calcification & & Calcification \\
Fenestrations/tears & & Degree \\
Cuspal abrasion & & Morphology \\
Cuspal stretching & & Location \\
Strut relationships & & Endothelialization \\
Mechanical dysfunction & & \\
Extrinsic interference/ & & \\
\multicolumn{1}{c}{ damage } &
\end{tabular}

prostheses and documentation of their most important pathologic findings have been described $(4,5,18)$. The specific type and model of the prosthesis may be identified using radiographic and morphologic keys $(4,8,120)$. A serial number placed by the manufacturer that uniquely identifies each valve is usually hidden under the sewing ring on the valve base.

In brief, a prosthesis at either autopsy or surgical removal is photographed from all pertinent angles and examined for thrombi, vegetations, exuberant tissue overgrowth, and structural defects. Autopsy specimens are carefully probed for paravalvular leaks. Mechanical heart valve prostheses are checked for adequacy of poppet excursion and seating, defects and fractures of components, asymmetries, sites of abrasive wear, and poppet swelling or distortion. Bioprostheses are gently examined to assess cuspal excursion and the presence of fenestrations, tears, cuspal hematomas, calcific nodules, and central migration of struts. Removing the valve from the stent, then opening and pinning it on cork aids characterization of gross cuspal pathology (Fig. 11). Routine morphologic analysis of bioprostheses includes radiography (we have used the Faxitron, Hewlett Packard, McMinnville, OR, $0.8 \mathrm{~min} \times 40 \mathrm{KV}$ ), that aids identification of the prosthesis type and assessment of calcific deposits. Calcification is semiquantitatively graded (usually, $0=$ not present, $1+=$ mild, $2+=$ moderate, $3+=$ more severe, and $4+$ $=$ most severe), and the location of calcific deposits noted (with respect to cuspal bodies, commissures, basal attachment sites, and at the free cuspal edges) (Fig. 12) (64). Specimens of cuspal and adherent tissue are specifically labeled and mounted in cross section for histologic analysis. Histologic analysis is directed toward determination of the morphology of tissue/prosthesis interactions, cuspal degen- 


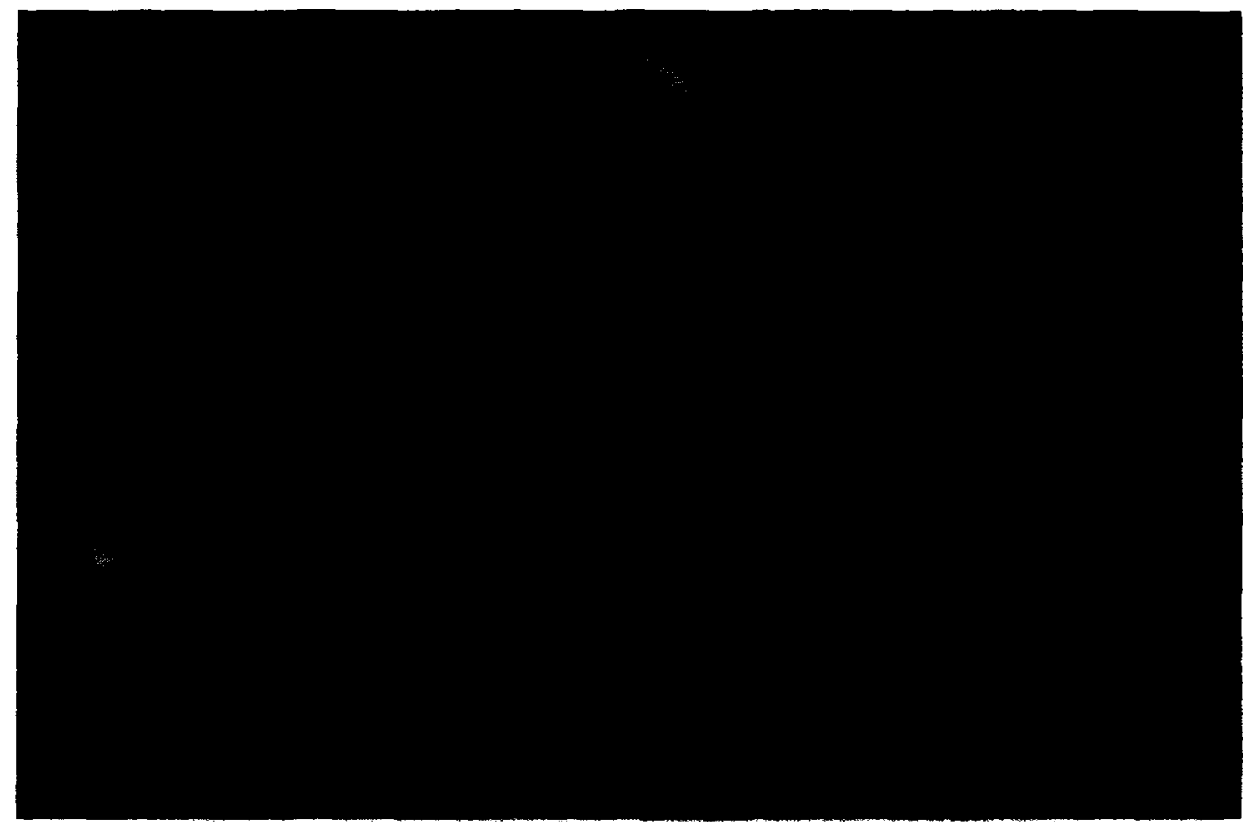

Figure 12. Composite radiograph of calcified porcine aortic valve bioprostheses, demonstrating the various levels of mineralization, $1+$ through $4+$, and providing radiographic standards for examination. Uncalcified $(0), 1+$ and $2+($ top $) ; 3+, 3+$ and $4+$ (bottom). (Reproduced from Schoen FJ, Kujovich JL, Webb CL, Levy RJ. Chemically determined mineral content of explanted porcine aortic valve bioprostheses: correlation with radiographic assessment of calcification and clinical data. Circulation 1987; 76:10611066. Copyright 1987, American Heart Association.)

Table 5. Implant Failure Analysis

Related to Design Feature
High stress
Abrasion
Tolerances too high or too low
Blood stasis
Related to Stock Material/Processing
Inclusions/bubbles/porosity
Heterogeneity
Weld defects/phase changes
Related to Device Assembly
Scratches
Cracks
Crush
Contamination
Related to Shipping/Storage
Freering
Contamination
Degradation
Related to Surgical Implantation
Scratches
Cracks
Crush
Suture entrapment
Related to Changes During Function
Fatigue
Abrasive wear
Cavitation
Biological degradation
Calcification

eration, and the degree and specific morphology of calcific deposits. Embedding in glycolmethacrylate allows sectioning of undecalcified specimens with good morphological preservation.

\section{Role of the Pathologist in Prosthetic Heart Valve Failure Analysis}

While not appropriate in the routine hospital setting, investigations using highly detailed implant retrieval and analysis elucidate mechanisms of prosthesis failure and thereby stimulate directed development of improved prostheses. Moreover, pathologists frequently participate as expert witnesses in product liability litigation involving cases of prosthetic valve failure. The essential objective in either situation is the assignment of a failure mechanism that distinguishes the relative roles of design, materials, fabrication, shipping, storage, implantation, and changes during function (Table 5). Determination of the etiology of an outlet strut fracture in a Bjork-Shiley $60^{\circ}$ convexo-concave tilting disk valve exemplifies general retrieval and analysis procedures that maximize obtainable data, without compromising further examination by other parties. This case illustrates the major factors in outlet strut failure, determined from evaluation of more than 20 explanted fractured BjorkShiley heart valves for which all three components (annulus with integral inlet strut, fractured outlet strut, and disk) were retrieved (121).

Outlet strut fatigue fractures in Bjork-Shiley convexoconcave valves have been attributed to abnormal loads and/ 
or welding flaws $(54,121)$. The source of these abnormal loads is illustrated in Figure 13A, a cross section of the valve through the midpoints of both the welded outlet strut (left, above) and integral inlet strut (right, below). Under normal conditions, the disc of the closed valve would be in a horizontal position and come to rest on the larger integral inlet strut. In the valve illustrated, abnormally high clearance between the inlet and outlet struts permits the disk to rotate in a clockwise direction beyond the horizontal plane, causing a hard contact with the tip of the outlet strut (indicated by arrow). This results in excessive bending stresses at and near the welds joining the outlet strut to the annulus; a marker for this abnormal loading is a pronounced wear flat on the tip of the outlet strut (Fig. 13B). In some cases, contact between the disk and the tip of the outlet strut is manifest by localized pyrolytic carbon wear deposits on the inlet strut near its junction with the annulus. Such deposits result from contact between the inlet strut and the periphery of the disk at the same time that the center of the disk is contacting the tip of the outlet strut. In other instances, abnormal motion leads to two distinct overlapping wear flats on the tip of the outlet strut.

The first outlet strut leg to fail invariably shows signs of extensive abrasion and wear resulting from the relative motion of the halves of this fractured strut as fatigue fracture of the second strut leg is occurring. Low magnification scanning electron micrographs of the fracture surfaces of the first and second strut leg to fail are shown in Figures $13 \mathrm{C}$ and 13D, respectively; slip bands from bending during manufacture are also evident on both strut legs. Both fractures initiated on the inlet side of the outlet strut, as in other valves that fractured. The first strut leg fracture typically initiates at or near the point of maximum bending stress in the center of the inlet strut leg/annulus junction. The initiation site in the second strut leg to fracture is often rotated slightly toward the first, since the remaining intact strut leg is subjected to both bending and torsion after the first fracture occurs.

Observations on the sides of an annulus and strut leg that have fractured are often useful in evaluating the mechanism of fatigue fracture and its relationship to microstructure and material flaws, especially in situations where there has been extensive abrasion and wear of the mating fracture surfaces of the initially fractured strut leg. Secondary cracks below the heavily abraded fracture surface of the first strut leg to fracture are associated with weld shrinkage porosity and/or inclusions (Fig. 13E).

Standards for use by experts in the product liability system developed by ASTM Committee E-40 on Technical Aspects of Product Liability Litigation are recommended for such analyses, including ASTM E-620-85(90) and E-678-84 (American Society for Testing and Materials, Philadelphia, PA). The detail shown in the above micrographs can only be observed if the devices are carefully preserved after explantation, particularly avoiding contact between fracture sur- faces, since wear patterns clearly provide valuable insights into the mechanism of failure. Destructive testing, such as sectioning, polishing, and etching the housing metal alloy, is useful in characterizing the valve microstructure and its relationship to fracture. However, such destructive testing should proceed only after all interested parties have had an opportunity to complete nondestructive tests, since potential observations may be precluded.

\section{Pathobiology of Bioprosthetic Valve Calcification}

In both circulatory and subcutaneous experimental models, bioprosthetic tissue calcifies progressively, with morphologic features similar to those observed in clinical specimens, but with markedly accelerated kinetics (122-124). Valves implanted into sheep or calves calcify extensively in 3 to 6 months, and subcutaneous implants of bioprosthetic tissue in young rats achieve calcium levels comparable to those of failed clinical explants in 8 weeks or less. We have utilized the subcutaneous implantation model extensively as a technically convenient, economically advantageous, and quantifiable model for investigating host and implant determinants and pathobiology of mineralization, as well as for screening and understanding the mechanisms of potential strategies for mineralization inhibition (122-131).

Clinical and experimental studies indicate that calcification of bioprosthetic valves depends on host, implant, and biomechanical factors $(1,4,122,132)$. Although calcification is most pronounced in areas of leaflet flexion, where deformations are maximal (i.e., cuspal commissures and bases), dynamic mechanical stress and strain are not prerequisites for calcification. Young age and renal failure potentiate mineralization, but the specific basis for age-dependent kinetics is uncertain $(122,132)$. In rat subcutaneous implants, calcification requires pretreatment of tissue with an aldehyde cross-linking agent; nonpreserved cusps do not mineralize in this model $(122,126)$. Glutaraldehyde-treated porcine aortic valve and bovine pericardium calcify comparably with respect to kinetics, extent, and morphology $(123,124)$. This suggests that the fundamental mechanisms of bioprosthetic tissue mineralization depend on specific biochemical modifications of implant microstructural components induced by aldehyde pretreatment.

Neither nonspecific inflammation nor specific immunologic responses appear to mediate bioprosthetic tissue calcification $(122,125)$. The tissue reaction associated with circulatory and subcutaneous porcine or pericardial valve implants is a classical foreign body reaction, primarily composed of nonlymphocytic mononuclear cells (i.e, macrophages) $(4,122)$. Although several experimental studies have suggested that bioprosthetic tissue can be immunogenic, despite both high collagen content and cross-linking $(133,134)$, 


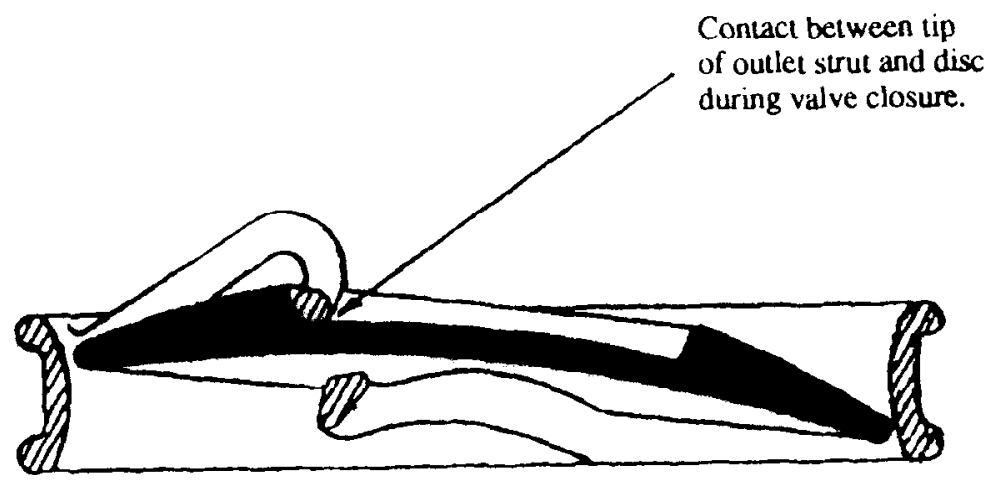

Figure 13. Bjork-Shiley convexo-concave valve fracture analysis (B-E are scanning electron micrographs). A. Cross section through center of valve showing contact between tip of outlet strut (cross-hatched circle) and disk (black) during valve closure. Contact area is indicated by arrow.

(A)

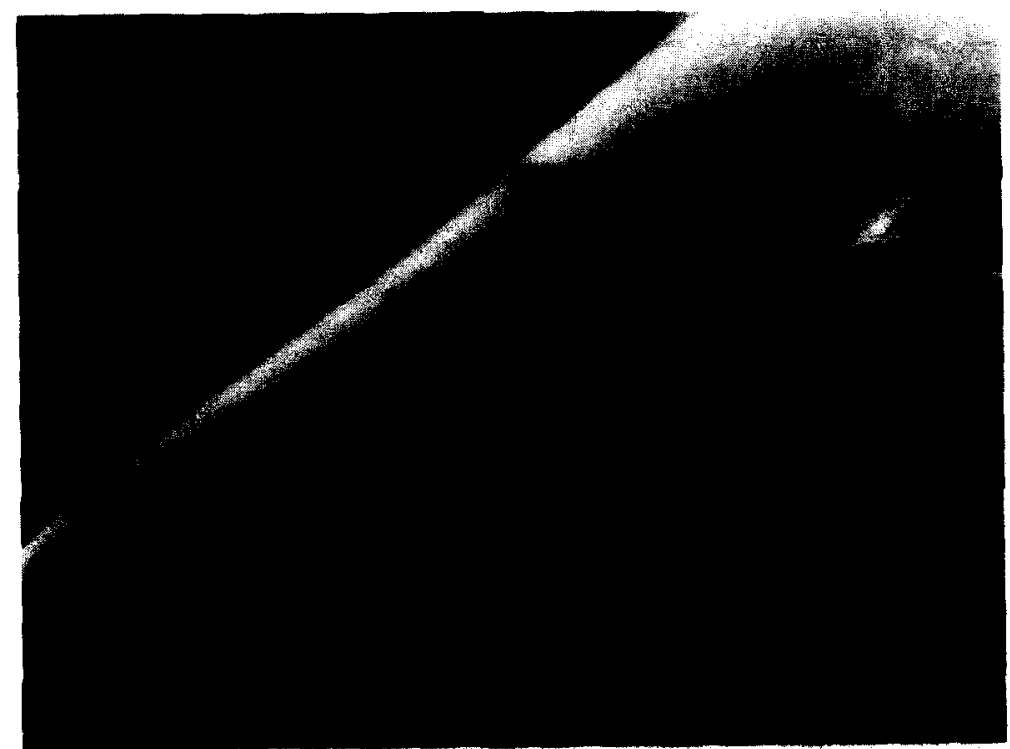

B. Elliptical wear flat on tip of outlet strut resulting from contact with disk during valve closure.

(B)

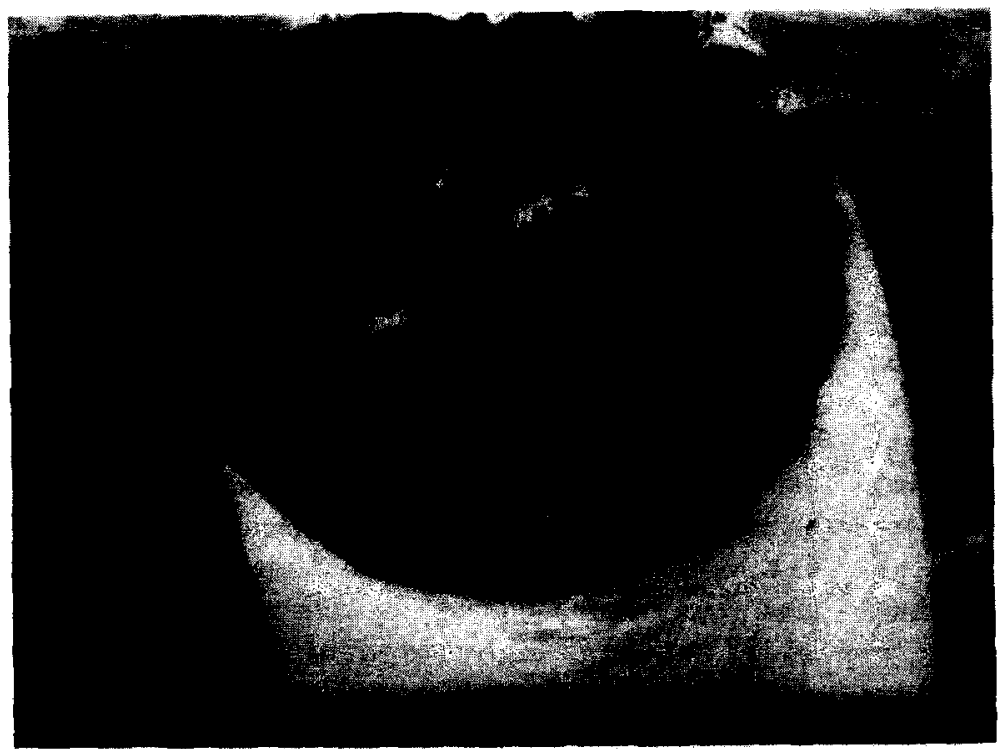

c. Worn and abraded fracture surface of first strut leg to fracture. Origin is at the bottom center. Slip bands from deformation during manufacture are present near origin. 
D. Fracture surface of second strut leg to fracture. Absence of pronounced wear and slip bands is apparent.

(D)

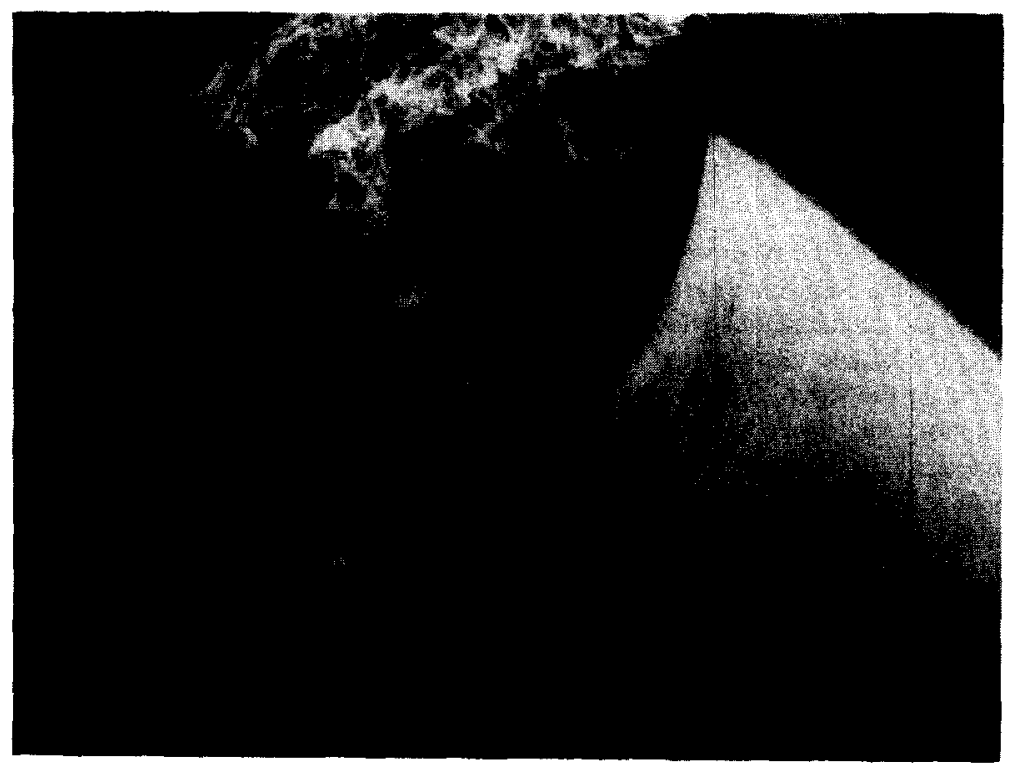

E. Slide of annulus near origin of fracture (top). Welding porosity and secondary cracking are present on the side of the annulus.

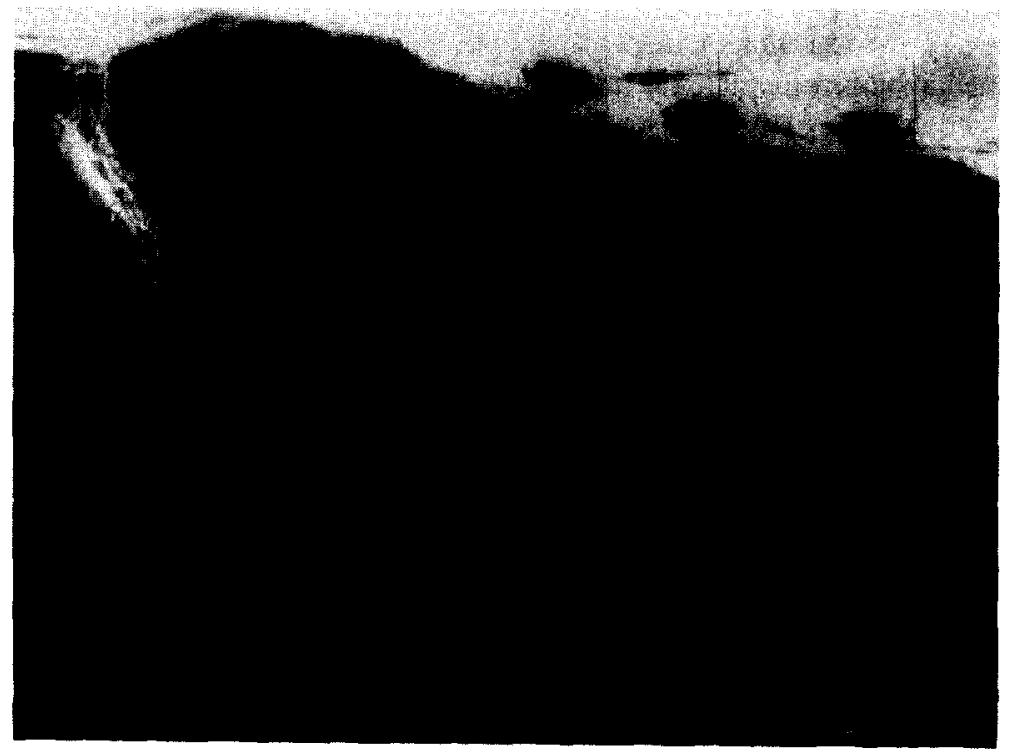

(E) 
Figure 14. Effects of preincubation in $1 \%$ SDS on calcification in a rat subcutaneous model of glutaraldehyde cross-linked porcine aortic valve. These results support the concept that phospholipid extraction is an important but perhaps not the only mechanism of SDS efficacy.

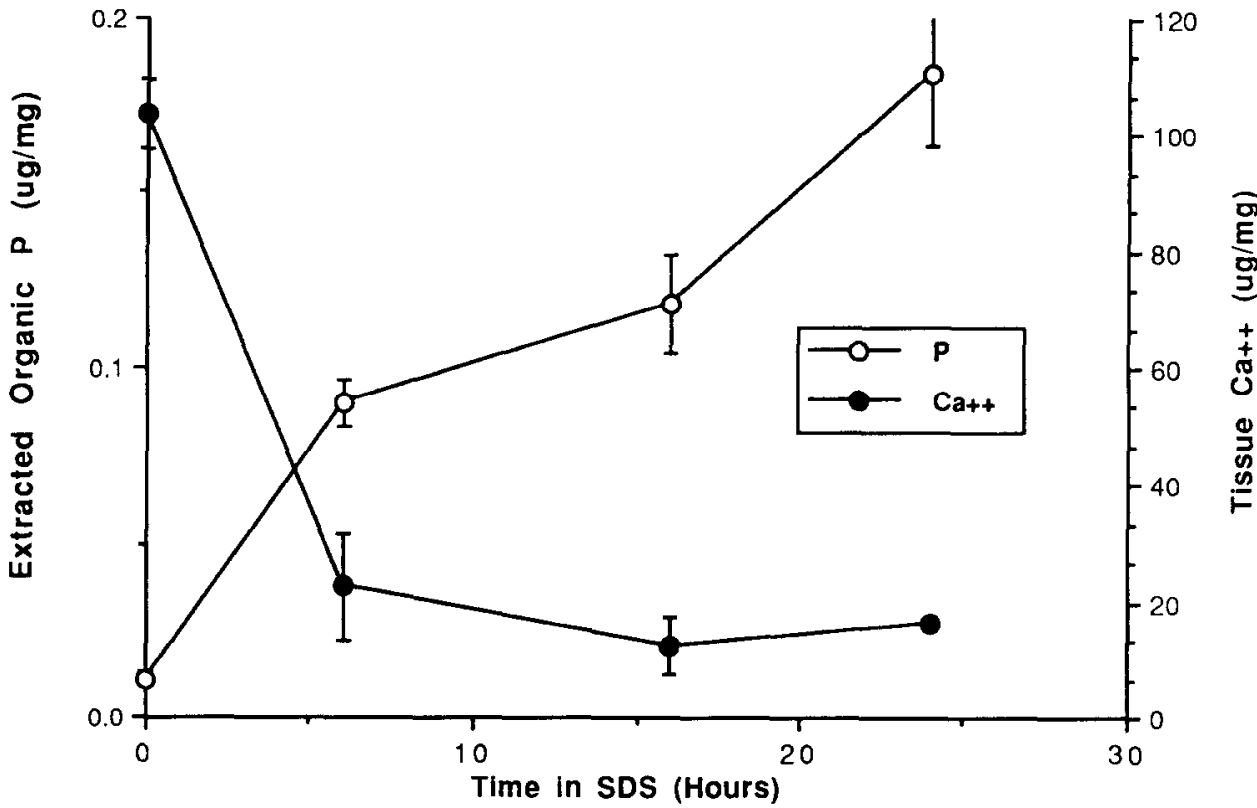

there is no evidence that immunological reactivity is causal to mineralization.

The earliest mineral deposits in both clinical and experimental bioprosthetic tissue are localized to transplanted connective tissue cells; collagen involvement occurs later (122124). As the implant period increases, cell-associated deposits increase in size and number, obliterating cells and dissecting among collagen bundles. Analogous to clinical valve failures, gross nodules focally obliterate implant architecture and ulcerate through the cuspal surface $(123,124)$.

Mineralization of the connective tissue cells of bioprosthetic tissue is hypothesized to result from glutaraldehydeinduced cellular devitalization and the resulting disruption of cellular calcium regulation (124). Intact living animal cells have low intracellular free calcium concentration (approximately $10^{-7} \mathrm{M}$ ), while extracellular free calcium is much higher (approximately $10^{-3} \mathrm{M}$ ), resulting in a 10,000 fold gradient across the plasma membrane. In healthy cells, cellular calcium is maintained low by energy-requiring metabolic processes, including the plasma membrane-bound $\mathrm{Ca}^{2+}$-ATPase, and intracellular binding by soluble cytosolic

Figure 15. Heavily calcified experimental polyurethane mitral trileaflet heart valve removed from sheep following 5 months implantation. A. Gross photo from distal aspect. B. Photomicrograph of extrinsic calcific deposits on cusp. (von Kossa stain [calcium phosphates black] $\times 175$.)

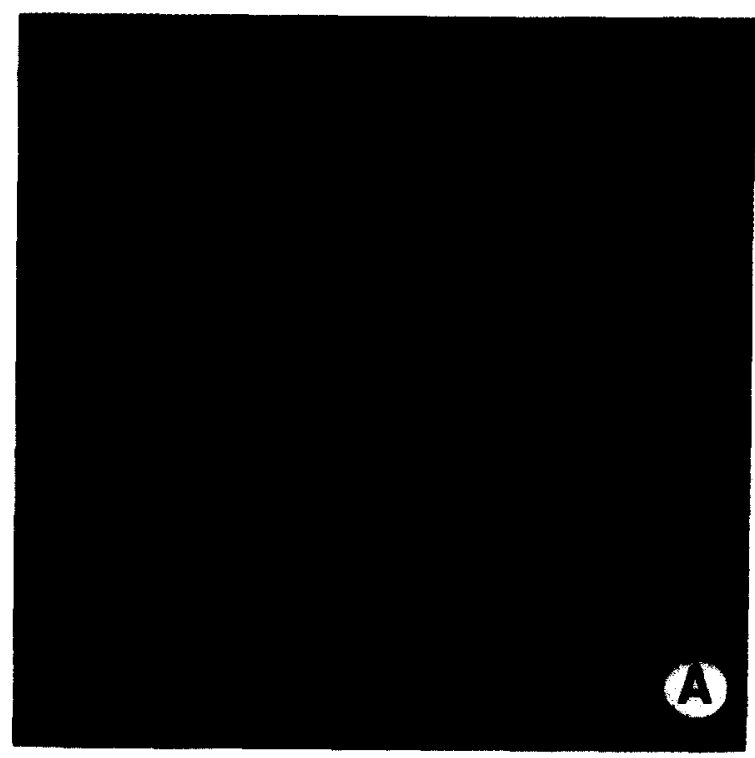

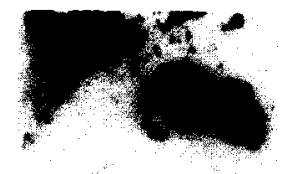

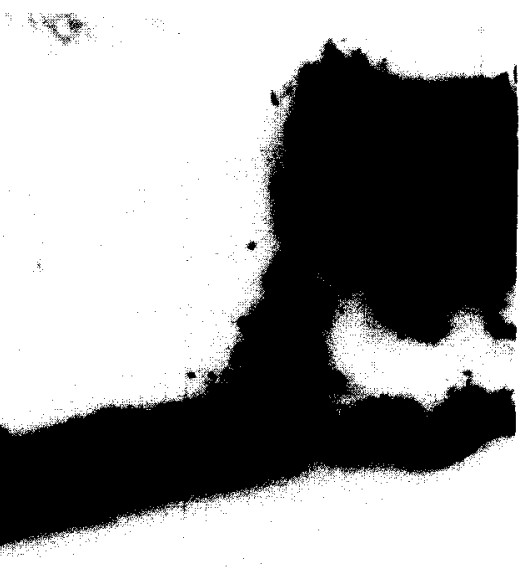


or membrane-bound proteins. Moreover, the observed sites of nucleation of bioprosthetic tissue mineralization (i.e, organellar and plasma membranes), contain considerable phosphorus, largely in the form of phospholipids. We hypothesized that passive calcium entry occurs unimpeded in cells modified by aldehyde cross-linking, but the mechanisms for calcium removal are dysfunctional. In this model, calcium influx contributes to apatite formation by reacting with compartmentalized, bound phosphorus. In support of the above hypothesis, we have demonstrated, using a newly available technique called electron energy loss spectroscopy (EELS), focally high concentrations of intracellular phosphorus in unimplanted, glutaraldehyde-preserved porcine aortic valve and bovine pericardium, and the progressive accumulation of calcium in tissues that have been implanted (131). The formation of calcium phosphate deposits occurs at these cellular sites as early as two days following implantation in the rat subcutaneous model. It is unknown whether collagen deposits are related to contiguous cell-oriented mineral deposition, or arise independently.

Pathologic calcification in the calcific diseases (e.g., degenerative calcific aortic stenosis, atherosclerosis) and the normal calcification of skeletal and dental tissues share important features: 1) initial mineral deposits are poorly crystalline apatitic mineral, highly insoluble in body fluids at physiological $\mathrm{pH}$, but able to proliferate in serum concentrations of calcium and phosphate; 2) cell and collagen crystal deposits are ultimately present, and 3 ) initial crystal formation occurs on cell membranes, usually in the form of extracellular vesicles (132,135-139). Interestingly, alkaline phosphatase, a matrix vesicle-associated enzyme critical to bone mineral nucleation, is present in both fresh and fixed bioprosthetic tissue, localized to sites where early mineralization occurs $(140,141)$. Alkaline phosphatase further accumulates in porcine aortic valve tissue, in both subcutaneous and circulatory sites, concurrent with mineralization onset (141).

\section{Enhancement of Bioprosthetic Valve Durability}

Several approaches are under investigation to reduce bioprosthetic valve failure by modifying host, implant, or mechanical influences. Modifications in cuspal configuration, valve design and tissue pretreatment procedures might enhance overall durability through lower mechanical stresses, thereby lessening structural damage, as well as reducing calcification.

Strategies for prevention of bioprosthetic tissue mineralization involve modifications of either valve preparation details or the local environment of the implant (132). Mechanisms of calcification inhibition by antimineralization treatments (AMTs) considered and/or investigated, clinically and/or experimentally, include extraction of calcifiable material, ionic and/or macromolecular binding to nucleation
Table 6. Anticalcification Studies-Sheep, Mitral, 5 Mos

\begin{tabular}{llrr}
\hline \multicolumn{1}{c}{ Treatment } & Type & N & Ca $(\mu \mathrm{g} / \mathrm{mg})$ \\
\hline Control (none) & PAV & 22 & $99.8+/-11.1$ \\
Control (none) & BPV & 17 & $104.3+/-9.1$ \\
Polysorbate-80 (PV2) & PAV & 15 & $7.6+/-2.6$ \\
Polysorbate-80 (PV2) & BPV & 11 & $55.2+/-12.7$ \\
Triton X-100, N-laurel sarcosine (PV2') & PAV & 17 & $24.4+/-1.8$ \\
Polyacrylamide (PV3) & PAV & 8 & $112.9+/-15.3$ \\
SDS (T6) & PAV & 17 & $17.7+/-4.2$ \\
SDS (T6) & BPV & 24 & $126.6+/-5.3$ \\
APDP & BPV & 12 & $126.6+/-7.3$ \\
Toluidine blue & PAV & 21 & $81.6+/-12.0$ \\
\hline
\end{tabular}

PAV, porcine aortic valve; BPV, bovine pericardial valve. Modified from M Jones et al. J Cardiac Surg 4:69, 1989.

sites, neutralization of critical cofactors, such as alkaline phosphatase (141), interference with calcium phosphate crystal growth, charge modification, alteration of interstitial tissue spaces by tissue compression or hydrogel infiltration, prevention of serum diffusion into cusps, and restoration of natural inhibitors. Diphosphonate compounds, used to treat metabolic bone disease, retard calcium phosphate crystal growth. In rats with subcutaneously implanted bioprosthetic tissue, either systemic therapy with ethanehydroxydiphosphonate (EHDP) or EHDP administered in the vicinity of the valve tissue from controlled-release drug delivery polymers loaded with the drug inhibit leaflet calcification (127-130). Cuspal modification by incubation in solutions of trivalent ions of aluminum or iron $\left(\mathrm{Al}^{3+}\right.$ or $\left.\mathrm{Fe}^{3+}\right)$ (131), elements associated with osteomalacia in renal dialysis patients (142), also inhibits mineralization. Our studies suggest that mitigation of mineralization derives from the association of aluminum or iron ions with devitalized cells, the sites of initial calcification (131). Although pretreatment in sodium dodecyl sulfate (SDS) also significantly inhibits calcification of porcine aortic valve tissue implanted subcutaneously in rats, results in experimental circulatory models have been inconsistent (143-146). Nevertheless, detergents, including SDS, are the only AMTs that have been demonstrated to be effective in circulatory implants (Table 6). Likely mechanisms of action of SDS could include the removal of phospholipids (Fig. 14), charge modification, or membrane-protein denaturation. Other compounds under investigation include covalently-linked protamine (147) and locally-administered phosphocitrate, a natural calcification inhibitor (148).

Preclinical determination of the efficacy and safety of AMTs includes four components: 1) initial qualification using heterotopic implantation (e.g., subQ in rats); 2) hydrodynamic/durability testing (e.g., pulse simulator, pulse accelerator); 3) morphologic studies of unimplanted material to assess treatment-induced degradation, and 4) valve replacement in an animal model. Clearly, however, bioprosthetic heart valve durability can be assessed with certainty only by long-term (>10 years) clinical evaluation. Efficacy and safety must be demonstrated for any strategy (Table 7). 
Table 7. Bioprosthetic Heart Valve Antimineralization Treatments: Criteria for Efficacy and Safety

Effectively inhibits calcification

$$
\text { Efficacy }
$$

Valve has adequate performance (i.e., unimpaired hydrodynamics and durability)

Determination of specific mechanisms of action

Dose-response relationship established

Effect not lost or inactivated during function

Neutralized component not reaccumulated

Does not merely delay onset of mineralization

Safety: Does Not

Cause adverse blood-surface interactions

hemolysis

platelet adhesion

coagulation protein activation

complement activation

inflammatory cell activation

binding of vital serum factors

Enhance local or systemic inflammation

foreign body reaction

immunological reactivity

hypersensitivity

Cause local or systemic toxicity

Potentiate infection

\section{Other Developments}

Since aortic valve replacement with relatively small valves may leave unacceptable gradients, attempts are being made to develop a stentless porcine aortic valve bioprosthesis (149). Such a valve would be glutaraldehyde-pretreated using conventional tcchnology, and implanted inside the aorta, thereby using the aortic root as the valve stent. This could not only greatly improve hemodynamics by allowing use of a larger valve but might improve durability by dampening cuspal mechanical stresses. Other developments include the use of low- or zero-pressure fixation and AMTs in commercial porcine valves presently in clinical trials $(150,151)$ and a custom-fabricated autologous pericardial valve with a novel stent construction (152).

Modest development of mechanical prostheses with new designs, particularly those using pyrolytic carbon occluders, has continued over the past decade, but it is unlikely that radical design changes will be soon forthcoming. Modification of tilting-disk configurations has concentrated on enhancing opening to improve hemodynamics, developing more durable supporting structures for the poppet, and reducing thromboembolic risk by eliminating metallic struts frum regions of stasis.

Attempts are being made to develop near-anatomic-configuration central flow trileaflet prostheses using synthetic polymers. Despite previous lack of success of synthetic trileaflet valves, due to poor tear resistance and calcification of the cusps $(4,132)$, reconsideration of the concept is now encouraged by major developments in the technology of polymeric materials, with implanted polyurethanes and other materials. Nevertheless, long-term durability limitations remain the major concern, with valve failures marked by tearing and/or calcification (153) (Fig. 15).

\section{References}

1. Schoen FJ. Cardiac valve protheses: pathological and bioengineering considerations. J Cardiac Surg 1987;2:65-108.

2. Rose AG. Pathology of Heart Valve Replacement. Lancaster: MTP Press, 1987:1-210.

3. Yankah AC, Hetzer R, Miller DC, Ross DN, Somerville J, Yacoub MH, eds. Cardiac Valve Allografts 1962-1987. New York: SpringerVerlag, 1988:1-394.

4. Schoen FJ. Interventional and Surgical Cardiovascular Pathology: Clinical Correlations and Basic Principles. Philadelphia: W.B. Saunders, 1989:1-415.

5. Schoen FJ. Pathology of bioprostheses and other tissue heart valve replacements. In: Silver, MD, ed. Cardiovascular Pathology, 2nd edi. New York: Churchill Livingstone, 1991:1547-1605.

6. Silver MD, Butany J. Mechanical heart valves: methods of examination, complications, and modes of failure. In: Virmani, R, Atkinson, JB, Fenoglio, JJ, eds. Cardiovascular Pathology. Philadelphia: W.B. Saunders, 1991:354-372.

7. Ferrans VJ, Hilbert SL, Fujita S, Jones M, Roberts WC. Abnormalities in explanted bioprosthetic cardiac valves. In: Virmani, R, Atkinson, JB, Fenoglio, JJ, eds. Cardiovascular Pathology. Philadelphia: W.B. Saunders, 1991:373-398.

8. Morse D, Steiner RM. Cardiac valve identification atlas and guide. In: Morse, D, Steiner, RM, Fernandez, J, eds. Guide to Prosthetic Cardiac Valves. New York: Springer Verlag, 1985:257-346.

9. Edmunds LH. Thrombotic and bleeding complications of prosthetic heart valves. Ann Thorac Surg 1987;44:430-445.

10. Dalen JE. Valvular heart disease, infected valves and prosthetic heart valves. Am J Cardiol 1990;65:29C-31C.

11. DiSesa VJ, Allred EN, Kowalker W, Shemin RJ, Collins JJ, Cohn LH. Performance of a fabricated trileaflet porcine bioprosthesis. Mid-term follow-up of the Hancock modified-orifice valve. J Thorac Cardiovasc Surg, 1987;94:220-224.

12. Ferrans VJ, Spray TL, Billingham ME, Roberts WC. Structural changes in glutaraldehyde-treated porcine heterografts used as substitute cardiac valves. Transmission and scanning electron microscopic observations in 12 patients. Am J Cardiol 1978;41:1159-1184.

13. Ishihara T, Ferrans VJ, Jones M, Boyce SW, Roberts WC. Structure of bovine parietal pericardium and of unimplanted Ionescu-Shiley pericardial valvular bioprostheses. J Thorac Cardiovasc Surg $1981 ; 81: 747-757$

14. Schoen FJ, Levy RJ, Ratner BL, Lelah M, Christie G. Biomaterials considerations for improved cardiac valve prostheses. In: Bodnar, E, Frater, R, eds. Replacement Cardiac Valves. Elmsford: Pergamon Press, 1991:357-381.

15. Bloomfield P, Wheatley DJ, Prescott RJ, Miller HC. Twelve-year comparison of a Bjork-Shiley mechanical heart valve with porcine bioprotheses. New Engl J Med 1991;324:573-579.

16. Schoen FJ, Titus JL, Lawrie GM. Autopsy-deternined causes of death after cardiac valve replacement. JAMA 1983;249:899-902.

17. Edmunds LH, Clark RE, Cohn LH, Miller DC, Weisel RD. Guidelines for reporting morbidity and mortality after cardiac valvular operations. J Thorac Cardiovasc Surg 1988;96:351-353.

18. Schoen FJ. Surgical pathology of removed natural and prosthetic heart valves. Hum Pathol 1987;18:558-567.

19. Bortolotti U, Guerra F, Magni A, et al. Emergency reoperation for primary tissue failure of porcine bioprostheses. Am J Cardiol 1987;60:920-921.

20. Cohn LH. Valve re-replacement in the asymtomatic patient. Ann Thorac Surg 1991;51:357-358. 
21. Levine MN, Raskob G, Hirsh J. Risk of haemorrhage associated with long term anticoagulant therapy. Drugs 1985;30:444-460.

22. Saour JN, Sieck JO, Mamo LAR, Gallus AS. Trial of different intensities of anticoagulation in patients with prosthetic heart valves. $\mathrm{N}$ Engl J Med 1990;322:428-432.

23. Wessler $\mathrm{S}$, Thye Yin E. On the mechanism of thrombosis. Prog Hematol 1969;6:201-232.

24. Yoganathan AP, Reamer HH, Corcoran WH, Harrison EC, Shulman IA, Parnassus W. The Starr-Edwards aortic ball valve: flow characteristics, thrombus formation, and tissue overgrowth. Artif Organs 1981:5:6-17

25. Yoganathan AP, Corcoran WH, Harrison EC, Carl JR. The Bjork-Shiley aortic prosthesis: flow characteristics, thrombus formation and tissue overgrowth. Circulation 1978;58:70-76.

26. Thiene G, Bortolotti U, Panizzon G, Milano A, Gallucci V. Pathological substrates of thrombus formation after heart valve replacement with the Hancock bioprosthesis. J Thorac Cardiovasc Surg 1980;80:414-423.

27. Anderson JM, Kottke-Marchant K. Platelet interactions with biomaterials and artificial devices. CRC Crit Rev Biocompat 1985;1:111 204.

28. Harker LA, Slichter SJ. Studies of platelet and fibrinogen kinetics in patients with prosthetic heart valves. New Engl J Med 1970;283:1302-1305.

29. Pumphrey CW, Dawes J. Elevation of plasma B-thromboglobulin in patients with prosthetic cardiac valves. Thromb Res 1981;22:147155.

30. Dewanjee MK, Solis E, Lenker J, et al. Quantitation of platelet and fibrinogen-fibrin deposition on components of tissue valves (IonescuShiley) in calves. Trans Am Soc Artif Intern Organs 1986;32:591594.

31. Steele P, Rainwater $\mathbf{J}$, Vogel R. Platelet suppressant therapy in patients with prosthetic cardiac valves. Relationship of clinical effectiveness to alteration of platelet survival time. Circulation 1979;60:910-913.

32. Harker LA. Clinical trials evaluating platelet-modifying drugs in patients with atherosclerotic cardiovascular disease and thrombosis. Circulation 1986;73:206-223.

33. Wilson WR, Danielson GK, Giuliani ER, Geraci JE. Prosthetic valve endocarditis. Mayo Clin Proc 1982;57:155-161.

34. Ivert TSA, Dismukes WE, Cobbs CG, Blackstone EH, Kirklin JW, Bergdahl LA. Prosthetic valve endocarditis. Circulation 1984;69:223-232.

35. Calderwood SB, Swinski LA, Waternaux CM, et al. Risk factors for the development of prosthetic valve endocarditis. Circulation 1985;72:31-37.

36. Arnett EN, Roberts WC. Prosthetic valve endocarditis. Clinicopathologic analysis of 22 necropsy patients with comparison of observations in 74 necropsy patients with active infective endocarditis involving natural left-sided cardiac valves. Am J Cardiol 1976;38:281-292.

37. Anderson DJ, Bulkley BH, Hutchins GM. A clinicopathologic study of prosthetic valve endocarditis in 22 patients: morphologic basis for diagnosis and therapy. Am Heart J 1977;94:324-332.

38. Muller WA, Cohn LH, Schoen FJ. Infection within a degenerated Starr-Edwards silicone rubber poppet in the aortic valve position. Am J Cardiol 1984;54:1146.

39. Bortolotti U, Thiene G, Milano A, Panizzon G, Valente M, Gallucci V. Pathological study of infective endocarditis on Hancock porcine bioprostheses. J Thorac Cardiovasc Surg 1981;81:934-942.

40. Ferrans VJ, Boyce SW, Billingham ME, Spray TL, Roberts WC Infection of glutaraldehyde-preserved porcine valve heterografts. Am J Cardiol 1979;43:1123-1136.

41. Tompkins LS, Roessler BJ, Redd SC, Markowitz LE, Cohen ML. Legionella prosthetic-valve endocarditis. New Engl J Med 1988;318:530-535.

42. Femandez-Guerrero ML, Muelas JM, Aguado JM, et al. Q fever endocarditis on porcine bioprosthetic valves. Clinicopathologic features and microbiologic findings in three patients treated with doxycycline, cotrimoxazole, and valve replacement. Ann Intern Med 1988;108:209-213.

43. Dhasmana JP, Blackstone EH, Kirklin JW, Kouchoukos NT. Factors associated with periprosthetic leakage following primary mitral valve replacement: with special consideration of the suture technique. Ann Thorac Surg 1983;35:170-178.

44. Hylen JC, Kloster FE, Starr A, Griswold HE: Aortic ball variance. Diagnosis and treatment. Ann Intern Med 1970;72:1-8.

45. Shah A, Dolgin AM, Tice DA, Trehan N. Complications due to cloth wear in cloth-covered Starr-Edwards aortic and mitral valve prosthesis and their management. Am Heart J 1978;96:407-414.

46. Schoen FJ, Goodenough SH, Ionescu MI, Braunwald NS. Implications of late morphology of Braunwald-Cutter mitral heart valve prostheses. J Thorac Cardiovasc Surg 1984;88:208-216.

47. Roberts WC, Fishbein MC, Golden A. Cardiac pathology after valve replacement by disk prosthesis. A study of 61 necropsy patients. Am J Cardiol 1975;35:740-760.

48. Silver MD, Wilson GJ. The pathology of wear in the Beall model 104 heart valve prosthesis. Circulation 1977;56:617-622.

49. Ridolfi RL, Hutchins GM. Detection of ball variance in prosthetic heart valves by liver biopsy. Johns Hopkins Med J 1974;134:131140.

50. Norenberg DD, Evans RW, Gundersen AE, Abellera RM. Fatal failure of a prosthetic mitral valve. J Thorac Cardiovasc Surg 1977;74:924-927.

51. Odell JA, Durandt J, Shama DM, Vythilingum S. Spontaneous embolization of a St. Jude prosthetic mitral valve leaflet. Ann Thorac Surg 1985;39:569-572.

52. Hjelms E. Escape of a leaflet from a St. Jude Medical prosthesis in the mitral position. Thorac Cardiovase Surg 1983;31:310-312.

53. Lindblom D, Bjork VO, Semb BKH. Mechanical failure of the BjorkShiley valve. Incidence, clinical presentation, and management. $J$ Thorac Cardiovasc Surg 1986;92:894-907.

54. Hiratzka LF, Kouchoukos NT, Grunkemeier GL, Miller C, Scully HE, Wechsler AS. Outlet strut fracture of the Bjork-Shiley $60^{\circ}$ convexoconcave valve: current information and recommendations for patient care. J Am Coll Cardiol 1988; 11:1130-1137.

55. A discussion of leaflet escape from the Edwards-Duromedics bileaflet valve. Clinical Data Report 14, Edwards CVS Division, Baxter Healthcare Corporation, Santa Ana, California, January, 1988.

56. Schoen FJ, Titus JL, Lawrie GM. Durability of pyrolytic carbon-containing heart valve prostheses. J Biomed Mater Res 1982;16:559-570.

57. Silver MD. Wear in Bjork-Shiley heart valve prostheses recovered at necropsy or operation. J Thorac Cardiovasc Surg 1980;79:693-699.

58. Foster AH, Greenberg GJ, Underhill DJ, McIntosch CL, Clark RE. Intrinsic failure of Hancock mitral bioprostheses: 10- to 15-year experience. Ann Thorac Surg 1987;44:568-577.

59. Milano AD, Bortolotti U, Mazzucco A, et al. Performance of the Hancock porcine bioprosthesis following aortic valve replacement: considerations based on a 15-year experience. Ann Thorac Surg 1988;46:216-222

60. Jamieson WRE, Allen P, Miyagishima RT, et al. The Carpentier-Edwards standard porcine bioprosthesis. A first generation tissue valve with excellent long-term clinical performance. J Thorac Cardiovasc Surg 1990;99:543-561.

61. Schoen FJ, Hobson CE: Anatomic analysis of removed prosthetic heart valves: causes of failure of 33 mechanical valves and 58 bioprostheses, 1980 to 1983 . Hum Pathol 1985; 16:549-559.

62. Walley VM, Giannoccaro P, Beanlands DS, Keon WJ. Death at cardiac catheterization: coronary artery embolization of calcium debris from Ionescu- Shiley bioprosthesis. Catheter Cardiovasc Diagn 1990;21:92-94.

63. Ishihara T, Ferrans VJ, Boyce SW, Jones M, Roberts WC. Structure and classification of cuspal tears and perforations in porcine biopros- 
thetic cardiac valves implanted in patients. Am J Cardiol 1981:48:665-678.

64. Schoen FJ, Kujovich JL, Webb CL, Levy RJ. Chemically determined mineral content of explanted porcine aortic valve bioprostheses: correlation with radiographic assessment of calcification and clinical data. Circulation 1987;76:1061-1066.

65. Kup[ GS, Geha AS, Hellenbrand WE, Kleinman CS. Fate of left-sided cardiac bioprosthesis valves in children. Arch Surg 1986;121:488490.

66. Ferrans VJ, Boyce SW, Billingham ME, Jones J, Ishihara T, Roberts WC. Calcific deposits in porcine bioprostheses: structure and pathogenesis. Am J Cardiol 1980;46:721-734.

67. Valente M, Bortolotti $U$, Thiene G. Ultrastructural substrates of dystrophic calcification in porcine bioprosthetic valve failure. Am J Pathol 1985;119:12-21.

68. Reul GJ, Cooley DA, Duncan JM, et al. Valve failure with the Ionescu-Shiley bovine pericardial bioprostheses: analysis of 2,680 patients. J Vasc Surg 1985;2:192-204.

69. Schoen FJ, Fernandez J, Gonzalez-Lavin L, Cernaianu A. Causes of failure and pathologic findings in surgically removed Ionescu-Shiley standard bovine pericardial heart valve bioprostheses: emphasis on progressive structureal deterioration. Circulation 1987;76:618-627.

70. Walley VM, Keon WJ. Patterns of failure in Ionescu-Shiley bovine pericardial bioprosthetic valves. J Thorac Cardiovasc Surg 1987;93:925-933

71. Wheatley D, Fisher J, Reece IJ, Spyt T, Breeze P. Primary tissue failure in pericardial heart valves. J Thorac Cardiovasc Surg 1987;94:367-374.

72. Bortolotti U, Milano A, Guerra F, et al. Failure of Hancock pericardial xenografts: is prophylactic bioprosthetic replacement justified? Ann Thorac Surg 1991;51:430-437.

73. Silver MD, Hudson REB, Trimble AS. Morphologic observations on heart valve prostheses made of fascia lata. J Thorac Cardiovasc Surg $1975 ; 70: 360-366$

74. Osinowo O, Monro JL, Ross JK. The use of glycerol-preserved homologous dura mater grafts in cardiac surgery: the Southampton experience. Ann Thorac Surg 1985;39:367-370.

75. O'Brien MF, Stafford EG, Gardner MAH, McGiffin DC, Kirklin JW A comparison of aortic valve replacement with viable cryopreserved and fresh allograft valves, with a note on chromosomal studies. J Thorac Cardiovase Surg 1987;94:812-823

76. Barratt-Boyes BG, Roche AHG, Subramanyan R, Pemberton JR, Whitlock RML. Long-term follow-up of patients with the antibiotic sterilized aortic homograft valve inserted freehand in the aortic position. Circulation 1987:75:768-777.

77. Matsuki O, Robles A, Gibbs S, Bodnar E, Ross DN. Long-term performance of 555 aortic homografts in the aortic position. Ann Thorac Surg 1988;46:187-191.

78. Kirklin JW, Blackstone EH, Maehara T, et al. Intermediate-term fate of cryopreserved allograft and xenograft valve conduits. Ann Thorac Surg, 1987;44:598-606.

79. Walker DK, Scotten LN, Brownlee RT. New generation tissue valves. Their in vitro function in mitral position. J Thorac Cardiovase Surg 1984;88:573-582.

80. Yoganathan AP, Chaux A, Gray RJ, et al. Bileaflet, tilting disc and porcine aortic valve substitutes: in vitro hydrodynamic characteristics. J Am Coll Cardiol 1984:3:313-320.

81. Schoen FJ, Schulman LJ, Cohn LH. Quantitative anatomic analysis of "stent creep" of explanted Hancock standard porcine bioprostheses used for cardiac valve replacement. Am J Cardiol 1985;56:110-114.

82. Roberts WC. Complications of cardiac valve replacement: characteristic abnormalities of prostheses pertaining to any or specific site. Am Heart J 1982;103:113-122.

83. Hansen DE, Cahill PD, Derby GC, Miller DC. Relative contributions of the anterior and posterior mitral chordae tendineae to canine global left ventricular systolic function. J Thorac Cardiovasc Surg 1987;93:45-55

84. Williams DB, Pluth JR, Orszulak TA. Extrinsic obstruction of the Bjork-Shiley valve in the mitral position. Ann Thorac Surg $1980 ; 32: 58-62$

85. Solem JO, Kugelberg J, Stahl E. Acute immobilization of the disc in the Bjork-Shiley aortic tilting disc valve prosthesis. Scand J Thorac Cardiovasc Surg 1983;17:217-219.

86. Ross EM, Roberts WC. A precaution when using the St. Jude medical prosthesis in the aortic valve position. Am J Cardiol 1984;51:231233.

87. Jarvinen A, Virtanen K, Peltola K, Maamies T, Ketonen P, Mannikko A. Postoperative disc entrapment following cardiac valve replacement. A report of ten cases. J Thorac Cardiovasc Surg 1984;32:152156.

88. Moke CK, Cheung DLC, Chiu CSW, Aung-Khin M. An unusual lethal complication of preservation of chordae tendineae in mitral valve replacement. J Thorac Cardiovasc 1988;95:534-536.

89. Jackson GM, Wolfe PL, Bloor CM. Malfunction of mitral Bjork-Shiley prosthetic valve due to septal interference. Am Heart J 1982;104:158-159.

90. Murphy SK, Rogler WC, Fleming WH, McManus BM. Retraction of bioprosthetic heart valve cusps: a cause of wide-open regurtitation in right-sided heart valves. Hum Pathol 1988;19:140-147.

91. Ziemer G, Luhmer 1, Oelert H, Burst HG. Malfunction of a St. Jude medical heart valve in mitral position. Ann Thorac Surg 1982;33:391-395.

92. Lester WM, Roberts WC. Fatal bioprosthetic regurgitation immediately after mitral and tricuspid valve replacements with Ionescu-Shiley bioprostheses. Am J Cardiol 1985;55:590-592.

93. Jones M, Rodriguez ER, Eidbo EE, Ferrans VJ. Cuspal perforations caused by long suture ends in implanted bioprosthetic valves. J Thorac Cardiovasc Surg 1985;90:557 -563.

94. Antunes MJ, Colsen PR, Kinsley RH. Intermittent aortic regurgitation following aortic valve replacement with the Hall-Kaster prosthesis. J Thorac Cardiovasc Surg 1982;84;751-754

95. Jett GK, Jett MD, Bosco P, van Rijk-Swikker GL, Clark RE. Left ventricular outflow tract obstruction following mitral valve replacement: effect of strut height and orientation. Ann Thorac Surg 1986; $42: 299-303$.

96. Clark RE, Grubbs FL, McKnight RC, Ferguson TB, Roper CL, Weldon CS. Late clinical problems with Beall model 103 and 104 mitral valve prostheses: hemolysis and valve wear. Ann Thorac Surg 1976;21:475-482.

97. Wong PH, Nandi PL, Ho FC.S, Chan TK. Acute intravascular hemolysis indicating thrombosis of Bjork-Shiley aortic prosthesis. Arch Intern Med 1983;143:1471-1472.

98. Lader E, Kronzon 1, Trehan N, Colvin S, Newman W, Roseff 1 . Severe hemolytic anemia in patients with a porcine aortic valve prosthesis. J Am Coll Cardiol 1983;1:1174-1176.

99. Roberts WC, Morrow AG. Renal hemosiderosis in patients with prosthetic aortic valves. Circulation 1966;33:390-398.

100. Harrison EC, Roschke EJ, Meyers HI, et al. Cholelithiasis: A frequent complication of artificial heart valve replacement. Am Heart $J$ 1978;95:483-488.

101. Goffin YA, Bartik MA, Hilbert SL. Porcine aortic vs. bovine pericardial valves: a morphologic study of the Xenomedica and Mitroflow bioprostheses. Z Kardiol 1986;75(Suppl 2):213-222.

102. Ishihara T, Ferrans VJ, Jones M, Boyce SW, Roberts WC. Occurrence and significance of endothelial cells in implanted porcine bioprosthetic valves. Am J Cardiol 1981:48:443-454.

103. Ishihara T, Ferrans VJ, Barnhart GR, Jones M, McIntosh CL, Roberts WC. Intracuspal hematomas in implanted porcine valvular bioprostheses. J Thorac Cardiovasc Surg 1982;83:399-407.

104. Thiene G, Bortolotti U, Talenti E, et al. Dissecting cuspal hematomas. 
A rare form of porcine bio prosthetic valve dysfunction. Arch Pathol Lab Med 1987;111:964-967.

105. Goffin YA, Gruys E, Sorenson G D, Wellens F. Amyloid deposits in bioprosthetic cardiac valves after long-term implantation in man. A new localization of amyloidosis. Am J Pathol 1984;114:431-442.

106. Ratliff NB, McMahon JT, Naab TJ, Cosgrove DM. Whipple's disease in the porcine leaflets of a Carpenticr-Edwards prosthetic mitral valve. Engl J Med 1984;311:902-904.

107. Schoen FJ, Hausner RJ, Howell JF, Beasley HL, Titus JL. Porcine heterograft valve replacement in carcinoid heart disease. J Thorac Cardiovasc Surg 1981;81:100-105.

108. Tuna IC, Orszulak TA, Schaff IIV, Danielson GK. Results of homograft aortic valve replacement for active endocarditis. Ann Thorac Surg 1990;49:619-624.

109. Hudson REB. Pathology of the human aortic valve homograft. Brit Heart J 1966;28:291-301.

110. Smith JC. The pathology of human aortic valve homografts. Thorax 1967;22:114-138.

111. Davies H, Missen AK. Blandford G, Roberts CI. Lessof MH, Ross DN. Homograft replacement of the aortic valve: a clinical and pathologic study. Am J Cardiol 1968;22:195-217.

112. Gavin JB, Herdson PB, Monro JL, Barratt-Boyes BG. Pathology of antibiotic-treated human heart valve allografts. Thorax 1973:28:473481.

113. Gavin JB, Barratt-Boyes BG, Hitchcock GC, Herdson PB. Histopathology of "fresh" human aortic valve allografts. Thorax 1973;28:482-487.

114. Brockbank KGM, Bank HL. Measurement of postcryopreservation viability. J Cardiac Surg 1987;2(Suppl):145-151.

115. Khatib HE, Thompson SA, Lupinetti FM. Effect of storage at $4^{\circ} \mathrm{C}$ in a nutrient medium on antigenic properties of rat aortic valve allografts. Ann Thorac Surg 1990;49:792-796.

116. Saravalli OA, Somerville J, Jefferson KE. Calcification of aortic homografts used for reconstruction of the right ventricular outflow tract. J Thorac Cardiovasc Surg 1980;80:909-920.

117. Maxwell L, Gavin JB, Barratt-Boyes BG. Differences between heart valve allografts and xenografts in the incidence and initiation of dystrophic calcification. Pathology 1989;21:5-10.

118. Maxwell L, Gavin JB, Barratt-Boyes BG. Uneven host tissue ongrowth and tissue detachment in stent mounted heart valve allografts and xenografts. Cardiovasc Res 1989;23:709-714.

119. Armiger LC, Thompson RW, Strickett MG, Barratt-Boycs BG. Morphology of heart valves preserved by liquid nitrogen freezing. Thorax 1985;40:778-786.

120. Mehlman DJ. A guide to the radiographic identification of prosthetic heart valves: an addendum. Circulation 1984;69:102-105.

121. Piehler HR, Nuhfer NT, James SP. Evaluation of outlet-strut fractures in Bjork-Shiley $60^{\circ}$ convexo-concave tilting disc prosthetic heart valves. Symposium on Retrieval and Analysis of Surgical Implants and Biomaterials, Society For Biomaterials, Snowbird, Utah 1988;p. 276.

122. Levy RJ, Schoen FJ, Levy JT, Nelson AC, Howard SL, Oshry LJ. Biologic determinants of dystrophic calcification and osteocalcin deposition in glutaraldehyde-preserved porcine aortic valve leaflets implanted subcutaneously in rats. Am J Pathol 1983;113:143-155.

123. Schoen FJ, Levy RJ, Nelson AC, Bernhard WF, Nashef A, Hawley M. Onset and progression of experimental bioprosthetic heart valve calcification. Lab Invest 1985;52:523-532.

124. Schoen FJ, Tsao JW, Levy RJ. Calcification of bovine pericardium used in cardiac valve bioprostheses. Implications for the mechanisms of bioprosthetic tissue mineralization. Am J Pathol 1986;123:134 145.

125. Levy RJ, Schoen FJ, Howard SL. Mechanism of calcification of porcine bioprosthetic aortic valve cusps: role of T-lymphocytes. Am J Cardiol 1983;52:629-631.
126. Golomb G, Schoen FJ, Smith MS, Linden J, Dixon M, Levy RJ. The role of glutaraldehyde-induced crosslinks in calcification of bovine pericardium used in cardiac valve bioprostheses. Am J Pathol 1987;127:122-130.

127. Levy RJ, Hawley MA, Schoen FJ, Lund SA, Liu PY. Inhibition by diphosphonate compounds of calcification of porcine bioprosthetic heart valve cusps implanted subcutaneously in rats. Circulation 1985;71:344-356.

128. Levy RJ, Schoen FJ, Lund SA, Smith MS. Prevention of leaflet calcification of bioprosthetic heart valves with diphosphonate injection therapy. Experimental studies of optimal dosages and therapeutic durations. J Thorac Cardiovasc Surg 1987;94:551-557.

129. Levy RJ, Wolfrum J, Schoen FJ, Hawley MA, Lund SA, Langer R. Inhibition of calcification of bioprosthetic heart valves by local controlled-rclease diphosphonate. Science 1985;229:190-192.

130. Johnson TP, Boyd JA, Ciesliga BL, Schoen FJ, Amidon G, Levy RJ. Controlled release of ethanehydroxy diphosphonate from polyurethane reservoirs to inhibit calcification of bovine pericardium used in bioprosthetic heart valves. Int J Pharm 1990;59:95-104.

131. Webb CL, Schoen FJ, Alfrey AC, Flowers WE, Horton C, Levy RJ. Inhibition of mineralization of glutarladehyde-pretreated bovine pericardium by $\mathrm{AlCl}_{3}$ and other metallic salts in rat subdermal model studies. Am J Pathol 1991;138:971-981.

132. Schoen FJ, Harasaki H, Kim KM, Anderson HC, Levy RJ. Biomaterial-associated calcification: Pathology, mechanisms, and strategies for prevention. J Biomed Mater Res 1988;22:11-36.

133. Bajpai PK. Immunological aspects of treated natural tissue prostheses. In: Williams DF, ed. Biocompatibility of Tissue Analogs. Boca Raton: CRC Press, 1985:5-25.

134. Dahm M, Lyman WD, Schwell AB, et al. Immunogenicity of glutaraldehyde-tanned bovine pericardium. J Thorac Cardiovasc Surg 1990;99:1082-1090.

135. Glimcher MJ. On the form and function of bone: from molecules to organs. In: Veis A, ed. Wolff's Law Revisited. The Chemistry and Biology of Mineralized Connective Tissues. North Holland: Elsevier, 1981:617.

136. Anderson HC. Calcific diseases. A concept. Arch Pathol Lab Med 1983;107:341-348.

137. Anderson HC. Mechanism of mineral formation in bone. Lab Invest 1989;60:320-330.

138. Kim KM, Valigorsky JM, Mergner WJ, et al. Aging changes in the human aortic valve in relation to dystrophic calcification. Hum Pathol $1976 ; 7: 47-60$.

139. Tanimura A, McGregor DH, and Anderson HC. Matrix vesicles in atherosclerotic calcification. Proc Soc Exp Biol Med 1983;172:173177.

140. Maranto AR, Schoen FJ. Alkaline phosphatase activity of glutaraldehyde-treated bovine pericardium used in bioprosthetic heart valves. Circ Res 1988;63:844-848.

141. Levy RJ, Schoen FJ, Flowers WB, Staelin ST. Initiation of mineralization in bioprosthetic heart valves: Studies of alkaline phosphatase activity and its inhibition by $\mathrm{AlCl}_{3}$ or $\mathrm{FeCl}_{3}$ preincubations. J Biomed Mater Res 1991;25:905-935.

142. O'Connor $\mathbf{M}$, Garrett $\mathbf{P}$, Dockery $\mathbf{M}$, et al. Aluminum-related bone disease: correlation between symptoms, osteoid volume, and aluminum staining. Am J Clin Pathol 1986;86:168-174.

143. Arbustini EI, Jones M, Moses RD. Modification by the Hancock T6 process of calcification of bioprosthetic cardiac valves implanted in sheep. Am J Cardiol 1984;53:1388-1396.

144. Jones M, Eidbo EE, Hilbert SL, Ferrans VJ, Clark RE. The effects of anticalcification treatments on bioprosthetic heart valves implanted in sheep. Trans Am Soc Artif Intern Organs 1988;34:1027-1030.

145. Jones M, Eidbo EE, Hilbert SL, Ferrans VJ, Clark RE. Anticalcification treatments of bioprosthetic heart valves: in vivo studies in sheep. J Cardiac Surg 1989:4:69-73. 
146. Lentz DJ, Pollock EM, Olsen DB, Andrews EJ. Prevention of intrinsic calcification in porcine and bovine xenograft materials. Trans Am Soc Artif Intern Organs 1982;28:494 497.

147. Golomb G, Ezra V. Prevention of bioprosthetic heart valve tissue calcification by charge modification: Effects of protamine binding by formalde hyde. J Biomed Mater Res 1991;25:85-98.

148. Tsao JW, Schoen FJ, Shankar R, Sallis JD, Levy RJ. Calcification of bovine pericardium used in bioprosthetic heart valves is retarded by the physiologic inhibitor, phosphocitrate, and a synthetic analog, administered locally. Biomaterials 1988;9:393-397.

149. David TE, Pollick C, Bos J. Aortic valve replacement with stentless porcine aortic bioprosthesis. J Thorac Cardiovasc Surg 1990:99:113118.
150. Oury JH, Angell WW, Koziol JA. Comparison of Hancock I and Hancock Il bioprostheses. J Cardiac Surg 1988;3:375-381.

151. Williams MA. The Intact bioprosthesis: early results. J Cardiac Surg 1988;3:347-351.

152. Love JW, Calvin JH, Phelan RF, Love CS. Rapid intraoperative fabrication of an autogenous tissue heart valve: a new technique. In: Bodnar E and Yacoub M, eds. Biologic \& Bioprosthetic Valves. 1986:691-698.

153. Hilbert SL, Ferrans VJ, Tomita Y, Eidbo EE, Jones M. Evaluation of explanted polyurethane trileaflet cardiac valve prostheses. J Thorac Cardiovasc Surg 1987:94:419-429. 